\title{
Economic and Strategic motivations for financial cooperation in East Asia
}

\author{
Young Il Park* \\ Seung Moon**
}

The 1997-98 financial crisis has had a profound effect on how East Asian economies the role of the IMF and its strategic interests relative to those of the United States in the international financial regime. It has prompted them to create a regional mechanism for financial and monetary cooperation, ranging from deeper policy dialogue and surveillance, to a system of financial cooperation, and common exchange rate arrangements. This paper analyses the economic and strategic motivations behind this and outlines recent developments in financial cooperation in East Asia to provide possible directions for the future.

A network of bilateral swap arrangements under the Chiang Mai Initiative(CMI) needs stronger policy dialogue and surveillance to develop into a regional financing facility, a sort of East Asian IMF. The facility plays a role as an regional lender of last resort,providing short-term funds to a member country facing a temporary liquidity shortage and for market intervention to stabilize foreign exchange rate. East Asian countries need to achieve regional exchange rate stability. In the long run, the region may develop a common currency arrangement, but it cannot be expected in the very near future because there is no convergence of macroeconomic conditions, economic structure and systems. A realistic approach would be for East Asian developing countries to adopt a currency basket system to minimize the impact of dollar/yen exchange rate volatility on their economies. Strong political will and a vision for regional integration will be required to introduce it.

\section{I. 머리 말}

1980 년대 이후 동아시아경제의 고도성장과정에서 무역 - 직접투자를 통하여 역내제국 사이에 경제적 상호의존관계가 심화되어 경제통합이 진전돼 왔다." 그러나 동아시아시장통합은 기본적으로 정부차원의 제도적 장치가 없이 민간부문의 이윤동기에 의한 시장력을 바탕으로 이뤄졌다.

통합 시장이 원만하게 작동하기 위해서는 각국의 제도와 정책을 조정할 정부차원의 협력이 필요하게 됐다. 그럼에도 불구하고 동아시아지역은 경제체제와 시스템, 발전단계가 다양하여 통합을 뒷받침할 정치 적 연대와 리더십의 부족으로 정부차원에서 제도적 장치를 마련하지 못한 상태에서 금융위기를 맞게 되었 다.

* Professor, School of International Trade and Regional Studies, Inha University, Incheon, Korea

**Ph.D. student, School of International Trade and Regional Studies, Inha University, Incheon, Korea.

" 동아시아경제의 대외 지향적 발전전략과 고도성장을 반영하여 1980 년에서 2000 년 사이에 역내교역의존도가 수출은 $39 \%$ 에서 $51 \%$ 로, 수입은 $39 \%$ 에서 $58 \%$ 로 증대하였으며 최근에는 유럽연합(EU) 역내교역비율에 근접할 정도가 되었다. 그 결 과 동아시아지역의 안정적인 발전을 위해서는 환율안정 등 금융통화분야의 헙력이 불가결한 조건으로 등장했었다(Park, 2003). 
1997-98년 외환위기는 동아시아제국의 경제협력을 정부차원에서 제도화하는 계기를 마련하였다. ${ }^{20}$ 우 선, 금융 - 통화면에서 IMF로 상징되는 글로벌체제에 대한 기본적인 인식이 바뀌게 되었다. 금융위기를 계 기로 동아시아제국은 역내금융시장이 얼마나 긴밀하게 통합되어 있는가를 확인할 수 있었으며, 금융위기에 대처하는데 있어서 IMF로 상징되는 글로벌체제의 한계와 실패를 절실하게 인식하게 되었다. 이러한 인식 을 바탕으로 외환위기의 재발을 방지하기 위해서는 지역차원의 공동대응이 필요하다는 공감도가 형성되어 글로벌체제를 보완하기 위한 제도적 메커니즘을 도입하기 시작했다.

금융 · 통화부문의 협력증진과 병행하여 무역 · 투자분야에서도 상호의존관계를 제도적으로 강화하기 위한 노력이 경주돼 왔다. 제 2 차 세계대전 이후 자유- 무차별원칙의 국제경제질서를 주도해온 미국과 유 럽지역에서 차별적이고 배타적인 지역주의가 급속도로 심화 - 확대됨에 따라 지역차원에서 대응할 필요성 이 제기되면서 동아시아지역에서도 지역통합 - 지역연대의 움직임이 태동하고 있다. 또한, WTO의 다자간 무역 - 투자자유화가 지지부진한 가운데, 지역주의가 다자주의와 반드시 상반되는 것이 아니라 오히려 글 로벌화를 촉진시킨다는 새로운 사고도 한 몫을 하고 있다. 기존에 동아시아지역에서 유일한 지역통합체였 던 ASEAN자유무역지대(AFTA)에 더하여, 최근에 일 - 싱가포르 사이에 경제연대협정(EPA)이 체결되 었으며, 한 · 일간,한 · 일 · 중 3국간, 중 - 아세안(ASEAN)간, 일 - 아세안간, 한 · 아세안간 등 수많은 자 유무역협정(FTA)이 논의되고, 이미 교섭이 진행되고 있다."

이 글은 금융위기 이후 동아시아에서 전개되고 있는 지역금융협력의 배경을 고찰하고 협력의 내용, 한 계와 문제점, 당면과제를 점검하고 앞으로 발전방향을 모색하는 것을 목적으로 한다. 다음 절에서는 경제 위기 이후 지역차원의 금융협력을 견인해온 경제적, 전략적 배경과 동기를 분석하고, 제 3 절에서는 지역금 융협력의 전개과정과 메커니즘을 소개하고 당면과제와 발전방향을 제시한다.

\section{II. 금융 · 통화협력 제도화의 배경}

1980 년대 이후 고도성장과정에서 역내무역과 투자가 급속하게 증가하여 역내제국 사이에 경제적 상 호의존관계가 증대하고 실질적인 시장통합이 진전됨에 따라 금융통화협력의 필요성이 지속적으로 제기되 어 왔었다.

v IMF는 경제위기(economic crisis)를 외환위기(currency crisis), 금융위기(banking crisis), 체계적 금융위기 (systemic financial crisis), 외채위기(foreign debt crisis) 등으로 구분하고 있다. 외환위기는 특정 통화에 대한 투기적 공격 으로 대외가치가 급속하게 하락하거나 정부의 개입으로 외환보유액이 급격하게 감소하는 경우를 말한다. 금융위기는 예금인출 쇄도로 은행의 예금지급불능상태에 이르거나 이를 막기 위해 정부가 대규모로 개입하는 경우를 의미한다. 체계적 금유위기는 금융시스템이 효율적으로 기능할 수 없어 실물경제의 혼란을 야기하는 상태를, 외채위기는 대외채무에 대한 원리금상환을 이 행할 수 없는 상태를 의미한다. 동아시아경제위기는 외한위기에서 출발하여 4 가지 경우를 모두 포함하고 있기 때문에 엄밀한 구분 없이 경제위기, 외환위기, 금융위기란 용어를 포괄적으로 사용한다.

" 최근까지 동아시아지역은 동남아시아국가연합(ASEAN)을 제외하고는 지역주의에서 상대적으로 자유로운 지역이었 다. 특히, 한국, 일본, 중국, 대만 등 동북아제국은 어떠한 형태의 지역주의(FTA)에도 참여하지 않고 GATT - WTO의 다자주 의에 충실하였다. 그러나 최근에 일본이 싱가포르와 경제연대협정(Economic Partnership Agreement, EPA)를 체결하고 멕 시코와 교섭을 완료하였으며, 한국이 칠레와 FTA를 조인하고 국회비준을 기다리고 있다. 현재 동북아의 지역협력은 단순한 정책협의단계를 넘어서 자유무역지대로 이행단계에 있으며, 학계에서는 시장통합, 더 나아가서는 통화통합에 이르기까지 보다 심화된 형태의 지역협력에 대한 논의가 붐을 이루고 있다. 중국은 ASEAN과 FTA 교섭에 착수하였으며, 일본도 ASEAN과 FTA교섭에 합의하였다. 한국과 일본은 FTA교섭을 위한 정치적 결단을 기다리고 있으며, 이는 장차 중국을 포함한 동북아자 유무역지대(NEAFTA)로 확대될 것이다. 또, 학계에서는 AFTA와 NEAFTA를 통합한 동아시아자유무역지대(EAFTA)까 지 논의되고 있다. 
그렇지만, 역내제국 사이에 경제발전단계의 다양성과 정부차원에서 금융통화협력을 제도화할 정치적 리더심이 뒷받침되지 않아 학술적 논의차원에 만 머물렀다." 그런데 1997년 외환위기를 계기로 강력한 추 진력을 얻어 ASEAN 10 개국과 한, 일, 중 등 동북아 3 개국으로 구성된 'ASEAN+3' 가 참여한 '치앙마이 구상' (Chiang Mai Initiative, CMI)의 '2국간 스왑협정' (Bilateral Swap Arrangement, BSI) 네트워크 를 중심으로 국제유동성지원메커니즘이 형성되기에 이르렀다. ${ }^{5)}$ 동아시아제국이 IMF가 주도하는 글로벌 시스템의 한계와 실패를 인식하고 지역차원에서 협력의 제도화를 위한 추동력을 얻을 수 있었던 배경과 동 기를 경제적 측면과 전략적 측면으로 나누어 살펴보기로 한다.

\section{1. 경제적 동기}

(1) IMF의 실패

동아시아의 금융협력의 제도화를 주장하는 경제적 논거는 다음 3 가지 측면에서 제기되었다. 첫 번째 동기는 1997-98 위기 시에 IMF의 한계와 실패, 특히 IMF 패키지의 정책이행조건(conditionality)에 대 한 비난과 불만에 초점을 맞추어졌었다. 먼저, IMF는 동아시아위기의 성격을 제대로 진단하지 못했었다. 태국에서 위기가 처음 발생하였을 때, IMF는 전통적인 총수요관리, 즉 과도하게 팽창적인 재정금융정책과 그로 인한 경상수지 적자의 확대에서 비롯된 것으로 진단하고 과혹한 긴축정책을 요구하였다. 그러나 후에 IMF 자신이 잘못을 시인한 바와 같이, 동아시아의 외환위기는 전통적인 '경상수지의 위기' 라기보다는 각 국경제에 대한 신뢰하락으로 외국자본이 급격하게 유출함으로서 야기된 '자본수지의 위기' 혹은 '금융시 스템의 위기' 였다. (Grenville, 1998; Yoshitomi · Shira, 2000). 더욱이 IMF는 잘못된 진단에 근거하여 요 구한 초긴축정책의 시정을 태만하여 위기발생국에 너무나 많은 희생을 안겨주었다.

$\mathrm{IMF}$ 의 정책요구조건에 대한 가장 큰 불만은 당시 위기발생국 상황에서는 감당할 수 없을 정도로 단기 간에 과혹한 구조개혁을 요구한데서 비롯되었다. 물론, 고도성장시기에 축적된 수많은 구조적 모순과 파행 성이 경제위기의 근본적 원인이고, 또 IMF 패키지가 기득권층의 저항을 견제하여 철저한 구조개혁을 가능 하게 한 긍정적 요인을 무시하는 것은 아니지만, 외환위기와 금융위기가 겹친 상황에서 당장에 총체적인 개혁을 실시한다는 것은 그 과정에서 엄청난 희생만을 강요하여 비현실적이라는 지적이 제기되었었다 (Yoshitomi · Ohno, 1999). 실제로 IMF 패키지는 위기가 절정에 달했던 1997-98년에 위기를 해결하기보 다는 위기를 더욱 악화시켰다는 평가와 비난이 초기부터 제기되었었다(Feldstein, 1998; Sachs, 1997; Martin, 1997).

- 동아시아제국의 금융통화협력의 필요성, 특히 실질적인 달러페그제도의 문제점을 지적하고 역내 환율안정을 유지하기 위한 협력메커니즘을 주장한 고전적인 연구서로서 Kwan(1994) 참조. Kwan은 1990년대 초에 이르기까지 일본경제의 역동적 성장과 퍼포먼스, 세계자본시장에서의 영향력 등에 착안하여 동아시아개도국들이 円화를 국제통화로 사용하고 엔에 대한 환율 안정을 유지할 필요가 있다고 주장하여 실질적으로 달러블록에서 독립하여 엔블록으로 발전해야 한다고 주장하였었다.

5) 'ASEAN+3' 은 1990년 말레이시아 마하티르수상이 1989년 공식적으로 발족한 아시아 - 태평양경제협력체(APEC)의 미국 주도에 반발하여 동아시아제국만으로 구성된 경제협력기구로 '동아시아경제그륩' (East Asia Asian Economic Grouping, 후에 East Asian Economic Caucus, EAEC로 개칭)을 제안하였는데, 그 회원국에서 홍콩과 대만만 제외되었다. $\mathrm{EAEC}$ 는 미국의 강력한 반대와 미국에 추종한 한국과 일본의 소극적인 자세로 실현되지 못했으나 외환위기 이후 $\mathrm{ASEAN}+3$ 의 형태로 실현되고 있다. 다만, 동아시아만의 협력체 창설에 저극 반대하는 미국의 입장을 고려하여 '동아시아' 란 말이 사용 되지 않고 있다고 하젰다. 
또한 IMF는 외환위기에 대처할 수 있는 여신지원능력에 한계를 보였다. 1990 년대 이후 외환위기의 대 부분은 자본시장의 글로벌화로 인한 금융시장의 위기, 즉 국제자본이동이 불안정을 반영한 '자본계정위 기' 로서 이에 효과적으로 대처하는데 필요한 막대한 자금규모에 IMF의 지원수단과 능력은 횔씬 미치지 못했다. 예를 들면, 동아시아위기 시에 IMF의 지원은 한국, 태국, 인도네시아가 지원받은 자금의 $1 / 3$ 에도 달하지 못했었다. 한편, IMF는 자체자금만으로 부족하기 때문에 위기발생국을 지원하기 위하여 다른 국 제기관이나 회원국정부를 동원하는 임무도 수행하고 있다. 문제는 동아시아위기 초기에 IMF가 국제협력 을 동원하는데 대단히 소극적이었으며, 실제로 미국과 유럽제국 등 역외선진국들은 2 국간 구제금융지원에 전혀 참여하지 안했었다는 점이다.

한편, 동아시아제국은 IMF 정책에 불만과 실망에도 불구하고 IMF의 의사결정에 자신들의 발언권을 강화할 수단이 거의 없다는 사실에 무력감을 느꼈다. 동아시아제국은 IMF이사회에서 전형적으로 과소대 표(under-represented)되고 있으며, 이것이 쉽게 시정될 전망도 없다. 동아시아제국(ASEAN5+3)은 세 계 GDP의 $20.86 \%$ 에 해당하는 경제력을 가지고 있음에도 불구하고 IMF의 쿼터지분은 $12.28 \%$ 에 불과하 다."

그렇다고 동아시아제국이 IMF의 무용론이나 철수를 주장하는 것이 아니다. 여전히, 국제금융통화질 서의 파수꾼으로서 IMF의 역할과 임무는 중요하다. 또한, IMF는 동아시아외환위기를 계기로 IMF도 자 금지원능력과 지원수단을 다양하게 강화하고 있다. 1997년 12월에 국제수지문제로 인하여 일시적으로 대 규모자금을 지원하기 위한 보충준비자금(Supplement Reserve Facility)제도를 도입하였으며, 기초경제 조건이 건전한 국가라도 금융위기 전염에 대비하여 기금차입협력을 체결할 수 있는 제도로서 1999년에 '예 방적 신용제도(contingent credit line, CCL)를 도입했다. ${ }^{81}$ 요체는 동아시아의 권익과 직결되는 국제경 제 - 금융에 관한 정책결정에 일정한 발언권을 확보하고 자신들의 문제를 주체적으로 해결하여 IMF가 실 패를 되풀이하지 않도록 보완할 수 있는 지역차원의 금융협력메커니즘을 창출할 필요성에 공감대가 형성 됐다.

\section{(2) 풍부한 외화보유}

경제적인 두 번째 동기는 동아시아지역은 지역전체로서 세계에서 가장 큰 저축초과지역이며, 역내 금 융협력체제만 구축된다면 유동성위기에 지역차원에서 충분히 대처할 수 있다는 자신감에서 비롯되고 있 다.

" IMF의 지원자금부족은 비단 동아시아지역에 국한하지 않고 모든 지역에 해당되기 때문에 동아시아제국만이 특별히 비난할 사항이 아니다. 참고로, 1997년 동아시아 위기 시에, 한국, 태국, 인도네시아 3 국에 제공된 총 1179억 달러 중에서 IMF 가 제공한 지원액은 $31 \%$ 에 해당하는 363 억 달러에 불과하였으며, 세계은행 (World Bank)과 아시아개발은행(ADB)이 269억 달러 $(23 \%)$ 를 지원하고 $46 \%$ 에 해당하는 547 억 달러는 2 국간 지원협정에 의하여 제공되었는데 거의 대부분이 역내 선진국인 일본이 제공하였었다(IMF, 1999).

${ }^{n}$ 1999년에 세계경제 및 금융질서에 관한 최고의 협의체인 G-3의 한 축인 일본이 ‘IMF 사무총장 유럽인, 제 1 부 총장 미 국인' 이라는 미 · 유럽간의 암묵적 합의에 도전하여 미국이 반대한 AMF구상을 제안한 재무성 국제금융담당차관 사카끼바라 씨를 IMF 사무총장후보로 추천한 일도 일본의 under-representation에 대한 항의로 해석됐었다.

s1 1997 년 12월에 한국은 보충준비금융제도에 의한 지원을 받았으며, CCL기금은 아직 한 건도 활용되지 않았다. 주된 이 유는 CCL의 차입헙약체결은 오히려 금융시장에 부정적인 신호로 작용하여 위기를 촉발시킬 우려가 있으며, 만약에 협약체결 과정에서 CCL의 자격요건에 미달한다는 사실이 알려질 경우에 시장의 신뢰를 상실하여 위기를 자초하게 될 우려가 있기 때문 으로 알려져 있다. 
현재 미국 밖에 있는 달러의 $85 \%$ 이상을 동아시아제국이 보유하고 있으며, 세계 6 대 외환보유국이 모 두 동아시아제국이다." 심지어, 외환위기가 발생했던 1997년 당시에도 동아시아지역의 외환보유고는 세계 전체의 $50 \%$ 에 달하는 600 억 달러에 달했었다. 문제는 동아시아의 저축이 역내의 투자자금으로 동원되지 않고 역외로 유출되는데 있다. 그 주요 이유로서는 지역의 금융시스템이 취약하고 금융시장이 발달하지 못 한데 기인하다. 즉, 차입자의 경영상태, 재무상태, 신용정보가 공개되지 않고 불투명하며, 역내 환율이 불 안정하고 금융기법이 발달하지 않아 거래비용과 투자리스크가 높기 때문이다. 따라서 동아시아의 저축을 역내투자로 전환하기 위해서는 지역차원에서 기업지배구조의 개선, 환율 안정화, 금융의 자유화와 국제화 가 필수적인 조건이다.

한편, 대외지향적 경제발전전략의 채택으로 개방도가 높은 동아시아제국의 경우에는 정상적인 경상거 래와 자본거래를 지속하기 위해서는 막대한 외화자산의 보유가 필요하다. 그러나 금융 - 자본시장의 세계 화 - 자유화로 어떤 나라도 일국차원에서는 아무리 많은 외화준비자산을 보유하더라도, 국제자본의 투기 적 공격으로부터 자유로울 수 없는 실정이다. 더구나 외화보유는 다른 용도로 활용할 수 있는 귀중한 자원 의 낭비이며. 동시에 국내통화량을 증가시켜 국민경제에 막대한 명시적, 잠재적 비용을 부담시킨다. 따라 서 금융의 세계화 시대에서 국제금융시장의 불안과 국제투기자금의 교란적 이동에 대해서는 지역적 차원 에서 대처할 필요가 있다.

Wade - Veneroso(1998)은 외환위기가 절정에 달했던 1998년에 동아시아지역에 자금협력메커니즘이 존재하지 않기 때문에 지역 전체로서 막대한 경제적 손실을 입었다고 지적했었다. 동아시아지역은 막대한 자금과잉상태에 있으면서도 역내금융협력메커니즘이 없어 자금잉여국은 $5 \%$ 이하의 금리로 미국 재무부 증권에 투자하거나 구미 금융기관에 예치하는 한편, 자금부족국은 $10 \%$ 이상의 금리로 구미 금융기관으로 부터 차입했었다. 만약 역내 자금시장을 이용한다면 투자국은 보다 높은 금리수입을 얻을 수 있고 차입국 은 금리부담을 줄일 수 있었을 것이라고 지적했다.

(3) 역내 환율안정의 중요성

동아시아지역에서 금융 - 통화협력의 제도화를 주장하는 세 번째 동기는 외환위기를 막고 안정성장을 유지하기 위한 전제조건으로 역내 통화 간 환율안정의 중요성에 초점을 맞추고 있다. 이미 수많은 연구들 이 외환위기 전에 동아시아개도국들이 채택한 달러페그제도(de factor dollar peg system)가 외환위기를 야기한 중요한 요인의 하나였다는 사실을 지적하고 있다(Ito - Ogawa-Sasaki, 1998; Kawai Akiyama, 2000; Kawai - Takagi, 2000). 동아시아개도국들의 대일경제관계를 고려할 때, 달러페그제는 국제외환시장에서 큰 폭으로 등락을 거듭하는 엔 - 달러환율변동에 의해서 각국의 수출과 경제성장이 매우 불안정한 영향을 받게 된다. 예를 들면, 1990 년대 중반부터 엔(円)화가 달러에 대해서 큰 폭으로 하락하면 서 동아시아개도국 통화의 대 엔화 환율의 급격한 상승으로 국제경쟁력이 저하하여 경상수지 적자가 확대 되었다. 이러한 경상수지의 대폭적인 적자가 환율하락압력으로 작용하고 국제외환시장이 외부충격에 취약 해지자 시장분위기가 일전하여 자본흐름이 대규모유출로 역전하여 외환위기를 촉발한 측면을 무시할 수 없 다.

" 예를 들면 2002년 말 현재 세계 주요 외환보유국은 일본 4624억 달러, 중국 2952억 달러, 대만 1661 억 달러, 한국 1214 억 달러, 홍콩 1118 억 달러, 싱가포르 805 억 달러로 6 위까지 랭크돼 있다. 물론 이런 현상은 동아시아에 지역협력체가 발달되지 않 았기 때문이며 통화통합단계에 이른 유럽제국은 일국차원에서 외환보유를 많이 준비할 필요가 없을 것이다. 
동아시아개도국의 실질실효환율의 불안정은 외환위기 이후에도 크게 개선되지 않고 있다. 외환위기 이후에 대부분의 동아시아개도국들이 변동환율제로 이행하였지만, 위기를 극복한 후 다시 실질적인 달러 페그제로 환원하고 있는 실정이다(Ogawa, 2000; Kawai, 2001). 이와 같은 실효환율의 불안을 방지하고 역내제국이 안정적인 성장을 지속하기 위해서는 역내 환율안정을 지향하는 지역통화협력체제의 구축이 필 요하다는데 공감대가 형성됐다.

\section{2. 전략적 동기}

앞에서 설명한 경제적 배경은 그 자체로서 대단히 중요하다. 그러나 단지 경제적 동기만으로 외환위기 이후 동아시아에서 태동하고 있는 지역주의의 전모를 이해하는데 충분하지 않다. 경제적 동기에 못지않게 동아시아의 지역적, 세계적인 차원, 특히 미국과의 관계설정에 있어 전략적 동기가 중요하다. 다만, 지역협 력의 제도화를 논의하는 과정에서 전략적인 측면이 명시적으로 표명되지 않은 이유는 경제적 측면에 초점 을 맞추는 것이 훨씬 설득력이 있고 상대국으로부터 역공을 피할 수 있기 때문이다. 특히 동아시아지역에 대한 미국의 정치군사적, 경제적 영향력을 고려할 때 더욱 그렇다.

\section{(1) 지역협력의 APEC형과 EAEC형}

전략적으로 가장 중요한 동기는 세계 유일의 패권국 미국과의 관계설정과 관련된다. 동아시아경제가 북미, 유렵과 함께 세계경제의 한 축으로 등장하기 시작한 1980 년대부터 동아시아에서는 역내경제협력을 추진하는데 미국을 포함한 아시아 - 태평양지역차원에서 APEC (Asia-Pacific Economic Cooperation) 형 협력과 미국을 제외하고 동아시아제국만으로 구성하는 EAEC(East Asia Economic Cooperation)형 협력의 2 개 흐름이 있었다. ${ }^{10} 1980$ 년대까지 미국은 다자주의원칙을 고수하여 APEC형 경제협력에도 소극 적인 입장이었다. 그러나 동아시아경제의 역동적 성장으로 시장규모가 확대되고 역내제국 간 상호의존관 계가 심화되어 하나의 거대시장으로 통합이 이루어지면서 적극적인 자세로 전환하였다.

100 아시아태평양지역의 경제협력체 결성에 관한 구상은 유럽의 지역주의가 시작된 1960 년대에 시작되었다. 그러나 본격적 으로 논의된 것은 동아시아경제의 고도성장, 중국의 개혁개방정책, 유럽지역주의의 심화와 확대, 미국 무역에서 태평양무역이 대서양무역을 상회하기 시작한 1980 년대부터이다. 1980 년에 태평양연안국가들의 학계, 재계, 관계 인사들로 구성된 민관협력 기구인 태평양경제협력위원회(PECC)가 발족하고, 1989 년에는 다자간 자유무역체제의 유지 - 강화를 추진하고 동시에 아 - 태 지역뿐만 아니라 세계경제 전체의 발전에 기여하기 위하여 '개방적 지역주의' (open regionalism)를 표방하고 APEC이 출범 하였다. 처음에 각료급회담으로 출범하였으나 1993년 미국 시애블 회담을 계기로 회원국 수뇌회담도 개최되기 시작했다. 1994 년에 '보고르선언' 을 채택하여 역내무역자유화를 추진하기로 결정하였으나 무역자유화의 기본방식, 범위, 추진일정, 비회원국 에 대한 대우 등 여러 분야에서 미국과 동아시아, 특히 ASEAN제국 사이에 입장차이가 커서 순조롭게 진행되지 않고 있다. $\mathrm{APEC}$ 은 처음에 12 개국으로 출범하였으나 3 차 서울회담에서 중국, 대만, 홍콩이 가입하고, 그 뒤 멕시코, 파푸아뉴기니, 칠레, 베트남, 페루, 러시아 등이 가입하여 현재 21 개 회원국에 달하고 경제체제, 경제발전단계는 물론 사회, 정치, 문화, 종교, 지리적 다양성으로 어떠한 실질적 헙력체로 발전하기에는 한계가 있다. 아태지역의 경제헙력체 형성의 역사적 전개에 대한 상세한 논 의는 박영일(1994), 동아시아의 경제협력체로서 APEC형과 EAEC형의 경합적 전개에 대한 상세한 논의는 Deng(1997) 참조. 
미국이 APEC에 적극적으로 참여한 가장 중요한 동기는 동아시아제국만의 독자적인 지역협력체 출현 을 견제하고 APEC에 참여하여 동아시아경제에 대한 영향력을 고수하려는데 있다." 일단 APEC에 참여 하자 미국은 APEC 차원의 무역자유화를 주도하였는데. 그 주된 동기는 첫째, 급속하게 성장하는 동아시 아시장을 개방시켜 미국경제의 활성화를 위한 받침대로 활용하고, 둘째, 당시에 부진하던 우르과이 라운드 (UR)를 조기에 성공시키고, 셋째, 시장통합의 심화 - 확대로 요새화돼가는 유럽연합(EU)에 대한 교섭력 을 강화하고, 마지막으로 종전에 2국간 협상을 통한 시장개방 압력을 APEC 차원의 무역자유화로 대체하 여 심각해지고 있는 동아시아에서의 반미감정을 완화시킬 필요성 때문이었다. (박영일, 1994). 요컨대 미국 은 동아시아시장을 개방시키는 압력으로 UR의 다자주의도, 2 국간 쌍무주의도 여의치 않자 APEC을 장 (場)으로 지역주의에 의한 압력수단을 강구한 것이다.

APEC 무역주의화를 실질적으로 주도한 미국에 대한 동아시아제국, 특히 ASEAN으로부터 완강한 반발로 무역자유화가 중대한 기로에서 는 순조롭게 진행되지 않았었다. 그런 과정에서 동아시아 경제위기 가 야기되었는데 동아시아지역의 유일한 협력기구인 $\mathrm{APEC}$ 은 위기에 아무런 역할도 하지 못했다. 그 결과 로서 APEC은 미국의 주장을 수용하여 FTA 형태의 제도적인 통합체로 발전할 것인가, 혹은 회원국 수뇌 들의 의례적인 의견교환의 장으로 머물 것인가의 기로에 서 있는데 현재로선 후자의 가능성이 더 크다고 할 수 있다(박영일, 2000).

한편, 말레이시아의 마하티르 수상은 1990년 유럽의 EU, 북미의 NAFTA, 미국 주도의 APEC에 대항 하여 다자간교섭에서 아시아제국이 협상력을 강화하기 위하여 미국을 제외한 동아시아만의 EAEC(Ease Asia Economic Cauaus) 구상을 제안하였다. 그러나 미국의 적극적인 반대와 미국의 입장을 고려한 한 국, 일본의 반대로 구체화되지 못했으나 동아시아경제위기를 계기로 ASEAN+3의 형태로 사실상 EAEC 형 협력체가 실현되고 있다. APEC의 역할과 기능이 한계를 보일수록 ASEAN+3은 EAEC형 협력체로 발전할 것이다. 이러한 전개는 기본적으로 경제협력의 신뢰할만한 파트너로서 미국에 대한 동아시아 인식 의 근본적인 변화를 의미한다.

\section{(2) 대미관계}

전통적으로 대부분의 동아시아제국은 지역의 안전과 번영에 대한 미국의 기여와 공헌을 높게 평가하 여 지역안보는 물론 국가안보를 미국에 의존하였으며, 무역과 투자에 있어서도 가장 중요한 파트너로 인식 하였었다. (Yamamoto - Thiparat - Ahsan, 2001). 그런데 경제위기를 계기로 미국이 취한 일련의 정책으 로 미국에 대한 동아시아인들의 불신이 고조되었다. 동아시아에서는 원래 외환위기를 야기한 환율불안정 은 근본적으로 미국의 '무해한 무시' (benign neglect) 외환정책에 기인한다는 인식이 지배했었다. 거기다 가 미국이 동아시아의 경제위기를 남의 문제로 방관하였으며, 심지어는 미국의 이익과 영향력을 확대하는 기회로 활용하는 것으로 비췄다. 따라서 동아시아인들은 자신들은 미국에게 한계적인 중요성밖에 없으며 동아시아의 질서를 미국에게만 의존할 수 없다고 생각했다.

우선, 1997년 9월 IMF · 세계은행 연차총회에서 일본이 제안하고 동아시아제국이 적극적으로 환영 한 '아시아통화기금' (Asia Monetary Fund, AMF) 구상에 미국은 IMF와 함께 노골적으로 반대하였다. 당시 미국과 IMF는 AMF의 업무가 IMF와 중복되고, AMF의 융자조건(conditionality)이 엄격하지 못 하여 도덕적 해이(moral hazard)를 야기할 우려가 있다는 이유로 반대하였다.

I"' 미국이 동아시아만의 경제협력체 형성에 대하여 얼마나 민감한가는 Bergsten(1997)에 잘 나타나 있다. 그는 '전통적으 로 미국대외정책의, 대외경제정책을 포함한, 핵심은 "태평양 가운데에 경계선을 그어 동아시아와 북아메리카를 인위적으로 분 단시키는"[전 미국무장관 James Baker 연설문 인용, 필자 주] 어떠한 제도적 장치도 피하는 것이었다. 미국은 EAEC 혹은 그 어떤 "동아시아만' 의 헙력체를 지향하는 말레이시아나 다른 국가의 제안을 단호하게 성공적으로 거부해 왔다' 고 지적하고 있 다. 
그러나 미국의 반대는 이미 앞에서 설명한 바와 같이, 미국을 배제한 동아시아만의 경제협력체에 반대 하는 전통적인 미국의 대아시아정책에서 비롯된 것이다.

둘째는 IMF에 대한 미국의 영향력과 관련된다. IMF에 대한 동아시아의 비난과 불만은 대부분 미국에 대한 실망과 배신감으로 표출됐다(Lee - Yang, 2001). 동아시아에서는 IMF의 주요 정책결정은 미국의 절 대적인 영향 아래 있다고 믿고 있다. 미국은 사실상 IMF 이사회의 주요의결사항에 거부권을 행사할 수 있 고, IMF 본부가 미국 재무부와 근접하여 상시로 의견을 교환하고, 여신제공과 융자조건을 결정하는 실권 자인 제 1 사무부총장이 관례적으로 미국 재무부출신이라는 점을 감안할 때 그러한 인식은 무리가 아니다. 따라서 미국이 자신들과 조금이라도 연대의식을 가졌더라면 IMF 패키지가 그렇게 과혹하지는 않았을 것 이라는 정서를 가지고 있다.

셋째는 패키지 교섭과정에서 IMF와 미국의 관료들의 권위주의적이고 오만한 자세가 아시아인의 자존 심을 훼손하여 반미감정으로 악화한 측면도 무시할 수 없다(de Brown, 2002). 한 때 ‘아시아의 기적' 을 낳 은 원동력으로 평가했던 유교적 집단주의와 교육을 중시하는 '아시아적 가치 '가 정경유착과 부정부패를 상징하는 '정실자본주의' (crony capitalism)의 원천으로 매도되고 총체적인 개혁을 요구하자 자존심을 잃게 되었다. ${ }^{2}$ 심지어 일부에서는 미국의 정책이 인종주의적이고 반아시아적인 것으로 받아들여졌다.

이 외에도, de Brown(2002)은 미국에 대한 실망과 환멸을 야기한 수많은 사례를 당시 관계자들의 증 언을 통하여 제시하고 있다. 먼저, 미국은 태국 바트화를 구제하기 위한 국제유동성지원계획에 참여하지 않아 태국인에게 배신감을 안겨주었다. ${ }^{13}$

다음은 미국이 금융위기를 이용하여 인도네시아 수하르트 정권을 붕괴시켰으며, 말레이시아의 마하트 르정권마저 붕괴시키려 했다고 믿고 있다. 실제로 동아시아의 민주화투쟁과 민주주의발전을 높이 평가하 면서 개발독재정권의 정실자본주의와 부패를 규탄하는 미행정부의 논평은 동남아제국을 당황하게 하였다.

마지막으로 동아시아경제위기를 촉발시킨 직접적 원인으로 헤지 펀드를 비롯한 국제투기성자금이 아 시아의 금융시장을 교란시킨 상당한 징후가 있었음에도 불구하고 미국은 그 개연성을 완강하게 부인하면 서 국제투기자본에 대한 규제에 반대하였다. ${ }^{14}$ 또 동아시아제국의 금융기관에 대한 구제금융에는 도덕적 해이를 이유로 완강하게 반대한 미국이 LTCM(Long-term Capital Management) 헤지펀드에 대해서는 금융시장과 금융기관을 교란시킬 우려가 있다는 이유로 1998년 9월 구제조치를 실시하였다. 아직도 동아시 아제국은 미국의 번영과 안전이 동아시아경제발전에 불가결한 조건이라는 사실을 인식하고 있으며, 따라 서 세계경제는 물론 동아시아경제에 있어 미국의 리더십을 수용하고 있다.

w World Bank 보고서(1993)는 활발한 투자와 기술혁신, 정부의 효과적이고 민완한 시장개입, 적절한 산업정책, 정부와 재계의 긴밀한 정보교환과 협력관계, 경제의 유연성과 자유시장경제체제 등이 동아시아경제 고도성장의 원동력으로 평가했었 다. 그러나 경제위기가 발발하자 이 모든 것들이 경제시스템의 취약성, 정책능력의 결여, 과도한 대외의존, 부정부패 등 구조적 결함의 근본요인으로 둔갑돼버렸다.

19 1997년 7월 태국의 바트화 위기에 당하여 태국에 금융지원을 제공한 나라는 일본(40억 달러), 호주 · 중국 · 홍콩 · 말레 이시아 - 싱가포르(각 10 억 달러), 한국 - 브루나이 - 인도네시아(각 5 억 달러) 등으로 호주를 제외하면 모두 동아시아국가가 참 여하고 미국은 불참하였다. 미국의 불참은 태국인에게 배신감을 불러일으켰다. 태국은 베트남 전쟁기간 중에 미국에 병참기지 를 제공하는 등 전통적으로 미국의 인도차이나 진출에 교두보역할을 하였으며, 최고의 동맹국이었다. 더구나. 일부 태국인들은 미국 재무성이 태국의 취약점을 더욱 폭로하여 위기를 더욱 악화시켰다는 견해까지 있었다.

w 1997 년 동아시아외환위기는 몇몇 혜지펀드가 동남아시아로부터 자본을 회수하자 이를 신호탄으로 국제투자가들이 앞 을 다투어 자본을 유출시킨 결과 되었다는 '소떼이론' 가설도 제기되었다. 동아시아외환위기에서 헤지펀드의 역기능에 대한 상 세한 논의는 Roubini(1998). 


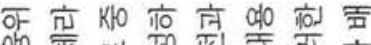
焉叫

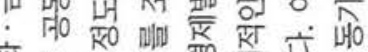

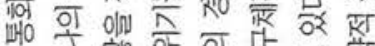

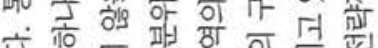

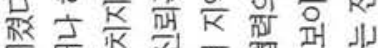
र

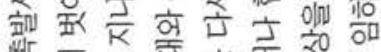
W

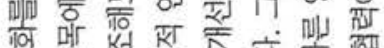

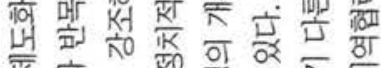

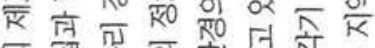

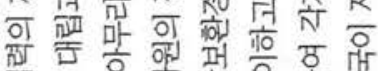
造

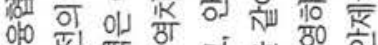
怕

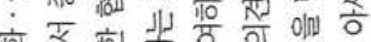

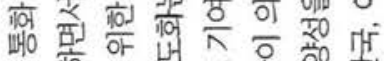
俩 of 매

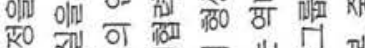

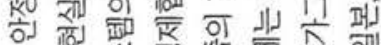

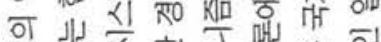
政 ए

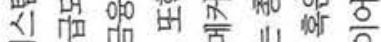

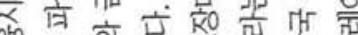

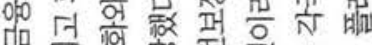

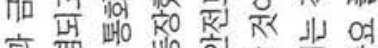

तो 年 袮 䓃六 㜿

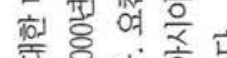
동 嵌 肪

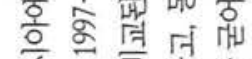
х

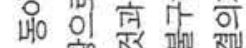
어 너에 너
带胥椋要

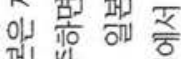
叫 J产望

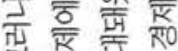
ㄱ. 需 맹 엎 远 펀 玄

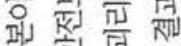

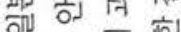
六 打

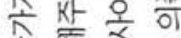
तf

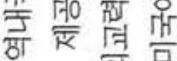
का क्र के वा on

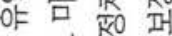

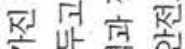

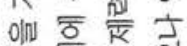

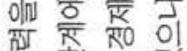
एव

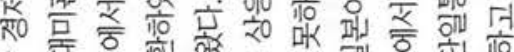
ion

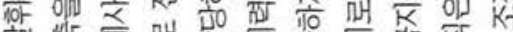

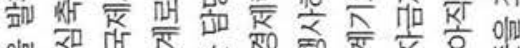

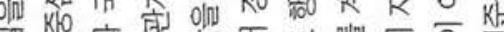

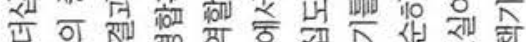

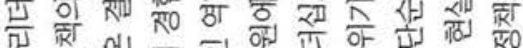
$\overline{\mathrm{C}} \mathrm{K}$ 和

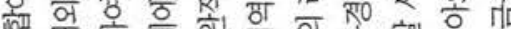
叫话

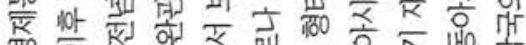
ए0

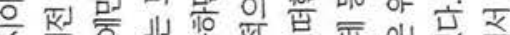

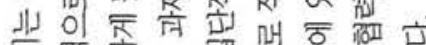
政 or $K$ oln का वा 떠 स्ति का का

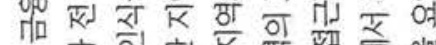

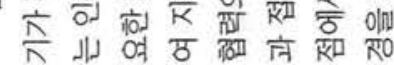

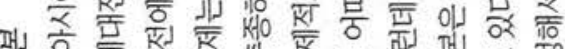

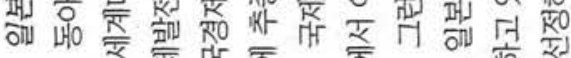

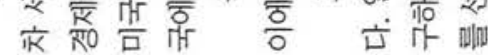

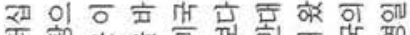

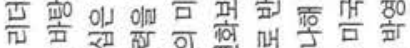

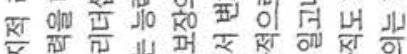

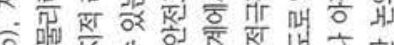

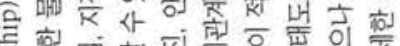

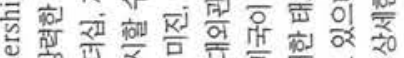
छ 业非

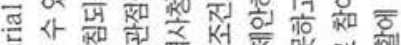

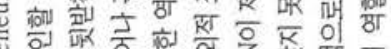
政似

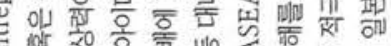

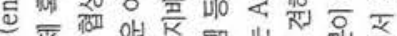

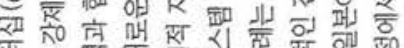
造 oln

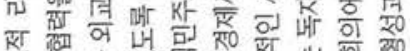

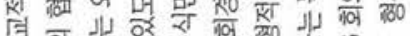

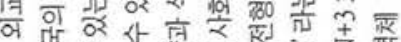

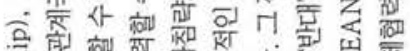

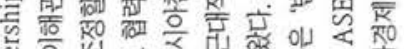
付

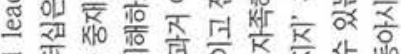
व्य एँ

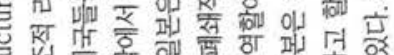
है तर 讦诰

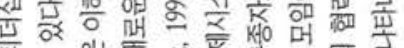

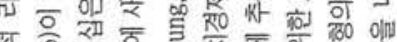

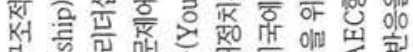

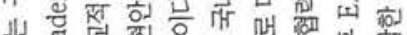
步 造 称

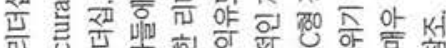

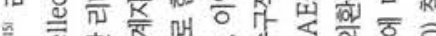

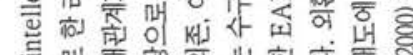


일본이 이렇게 적극적인 입장을 취하게 된 배경에는 1990 년대 이후 지속된 일본경제의 장기침체와 중 국경제력의 급격한 부상, 미국에 버금가는 단일경제권으로 통합된 유럽연합(EU)의 등장 등 대내외적인 환경변화로 지금까지 지켜왔던 G-3의 한 축으로서 위상마저 위협받고 있다는 위기의식이 있다. 구체적으 로, 첫째, 제도적 통합을 계기로 시장개방과 구조개혁을 가속화하여 경제시스템의 합리성과 효율성을 제고 하며, 둘째, 동아시아의 안정된 통화시스템을 마련하여 성장잠재력을 확대하고 엔화의 국제적 역할을 높이 고, 셋째, 무역 - 투자 등 실물부문의 시장통합을 적극 추진하여 민간기업의 지역네트워크를 활용하여 국제 경쟁력을 강화하기 위한 것이다. 현재 일본은 경제대국으로 급격하게 부상하고 있는 중국과의 관계를 재설 정하는 한편, 동아시아제국과 쌍무적 FTA를 적극 추진하면서 동아시아전체의 경제통합까지 검토하고 있 다.

\section{중국}

동아시아의 정치대국인 중국은 미국의 패권뿐만 아니라 일본의 리더십도 경계하고 있다. 1997년 일본 이 제안한 AMF구상에 중국이 소극적인 반응을 보였던 것도 일본의 주도를 견제하려는 의도로 해석됐었 다. 한편 국제협력의 경험이 없었던 중국은 1998 년 외환위기가 절정에 달했던 상황에서 위안(元)화 환율을 유지하여 국제협력의 모범을 보여 국제적으로 신뢰를 획득한 바 있다. 금융 - 외환시장이 극도로 불안정했 던 당시에 위안화마저 절하되었다면 동아시아경제의 혼란이 더욱 악화하여 회복과정이 무척 더디었을 것 이다(박영일, 2000).

2000 년대에 들어와서 대내외적인 경제여건이 크게 변화하면서 금융통화협력에 소극적인 자세에서 전 환하기 시작하였다. 먼저, 중국경제의 역동적인 성장이 지속하고 오랜 숙원이었던 WTO 가입이 이루어지 면서 세계경제 및 지역경제에서 위상이 급속도로 부상하고 있다. 자국경제에 대한 중국인의 자신감과 프라 이드가 높아지는 반면에, 국제사회로부터 견제도 증가하고 있다. 이미 미국을 비롯한 국제사회는 중국에 위안화 절상과 시장개방을 강력하게 요구하고 있다. 이 과정에서 중국도 동아시아경제통합에 적극적인 자 세로 전환하고 있다. 그 대표적인 사례가 ASEAN제국과 FTA 체결 합의라고 할 수 있다. ${ }^{16}$

한편 중국도 금융 - 통화분야에서 미국이나 IMF에 대한 과도한 의존이나 개입을 원하지 않기 때문에 지역차원에서 금융협력을 강화하는데 원칙적으로 공감하고 있다. 다만, 국내금융시스템과 금융시장이 취 약하고 금융자유화가 미진하여 자본거래에 대한 엄격한 규제를 계속하고 있는 현실을 감안하여 금융 - 통 화협력은 장기적인 안목에서 단계적으로 추진할 것을 주장하고 있다. 현재 중국은 $\mathrm{CMI}$ 의 2 국간 통화스왑 을 다자간 스왑으로 발전시키며, 통화위기의 재발을 방지하기 위하여 조기경보시스템을 구축하고, 역내환 율안정을 위한 공조, 아시아채권기금을 우선적으로 추진하며 금융정책기준의 일치를 요구하는 공동환율제 나 단일통화의 도입은 아직 시기상조라는 견해를 피력하고 있다.

\section{ASEAN}

ASEAN은 1967년 방콕선언으로 역내협력기구로 출범하여 1970년대 초까지 경제협력보다는 지역안보 와 평화유지를 위한 정치적 연대에 비중을 두었었다."

w1 중국이 ASEAN과 FTA체결을 추진한 배경은 첫째, ASEAN제국에서 대두되고 있는 '중국위협론' 을 불식하고 동남 아지역에서 정치적, 경제적 신뢰관계와 영향력을 강화하고, 둘째, 동남아지역의 풍부한 석유· 에너지자원을 확보하며, 셋째, 동남아 화교자본을 유치하여 장기적으로 '동아시아중화경제권' 을 형성하며, 마지막으로 미국에 대한 무역의존도를 줄일 수 있 다는 점을 들 수 있다. 보다 상세한 논의는 Zhang(2003) 참고.

${ }^{17}$ ASEAN은 1967년 인도네시아, 말레이시아, 필리핀, 실가포르, 태국 등 5 개국으로 출범하였으나 1980년대에 브루나이 가 가입하고, 1995 년 베트남, 1997 년 라오스, 미얀마, 1998년 캄보디아가 가입하여 현재 10 개국으로 구성되어 있다. 
그러나 베트남전쟁이 끝난 후 1976년에 개최한 제1차 정상회담에서 '동남아협력조약' 과 'ASEAN 협 력선언' 을 채택하고 경제협력기구로 성격을 전환하여 ASEAN산업계획(1976), 특혜무역협정(1977), ASEAN산업보완계획(1981) 등 다양한 산업 및 무역협력에 착수하였다. 그러나 회원국 간에 경제적인 보 완관계보다는 경쟁관계가 강하여 경제협력의 수준과 속도가 기대만큼 진전되지 못했었다. 1980 년대에는 세계적인 보호무역주의와 구미지역에서 지역주의가 심화되고 있는 가운데, ASEAN제국은 경제개발전략 을 수출지향과 외국인자본 유치 등 대외개방형으로 전환하면서 역내국간 교역 및 산업협력의 필요성이 더 욱 절실하게 되었으며 ASEAN 자유무역지역 창설에 착수했다. ${ }^{18} 1992$ 년 제 4 차 정상회담에서 'ASEAN 경제협력을 위한 기본협정' 을 체결하고 1993년 1월1일부터 15년간 단계적으로 역내공산품에 대한 관세를 $0.5 \%$ 수준으로 인하하는 공동유효특혜관세(common effective preferential tariff)제도를 도입하여 $\mathrm{AFTA}$ (아세안자유무역지역)를 공식 출범시켰다.

ASEAN제국은 경제발전단계의 다양성과 이로 인한 경제적 이해관계의 경합과 대립으로 동아시아경 제통합에 대한 ASEAN의 목소리를 하나로 묶어내는데 한계가 있다. 또 ASEAN은 주권존중 내정불간섭 의 원칙을 고수하고 있어 협력추진에 취약점이 있다. 일반적으로 '최소공약수' 방식으로 의사가 결정되며, 각국이 '총론 찬성, 각론 반대' 의 성향이 강하여 일단 합의된 사항도 실천에 옮기기가 어렵다. ASEAN이 형성된 지 36년이 되지만 아직도 협력수준이 대단히 낮은 것도 이 때문이다. ASEAN이 1980년대 후반부 터 동북아제국을 포함한 $\mathrm{EAEC}$ 형 경제협력을 강력하게 주장한 배경에는 경제구조가 상호 경쟁관계에 있 는 회원국간 협력의 한계를 인정하고 경제적 보완도가 높은 동북아제국과 통합함으로서 시장통합의 이익 을 극대화할 수 있다는 판단이 작용하고 있었다.

한편, ASEAN은 자신들의 결집력을 활용하여 역외제국과의 관계에서 리더십을 발휘하여 왔다. 미국 이 주도하는 APEC형 협력에 대항하여 EAEC형 협력체를 주장한 것이나 APEC 무역자유화를 미국이 주 도하면서 그 성격이 '개방적 지역주의' 에서 'FTA형태의 지역통합체' 로 전환할 움직임이 나타나자 이에 강 력하게 견제한 것이 좋은 사례이다. 또, 미국의 영향력을 상쇄하기 위하여 아시아 · 유럽수뇌회의(ASEM) 창설에 주도적 역할을 하였다. ${ }^{19}$ 또한 ASEAN은 ARF(ASEAN지역안보포럼)를 주도하여 동아시아지역의 안전보장문제를 집단적으로 협의하고 정치군사적 정보를 교환할 수 있는 정례포럼을 창설하였다.

ASEAN 입장에서 보면, 경제적 보완도가 높은 동북아 3개국을 포함한 동아시아 전체를 아우르는 금 융협력체의 창설은 외환위기의 재발을 방지하고 금융시장의 안정을 위한 불가결한 조건이다. 따라서 각국 의 발전단계를 반영하여 전략적 이해관계는 다르지만, 모든 회원국이 동아시아통합을 적극적으로 지지하 고 있다. (Ariff, 2003; Feridhannusetyawan, 2003; Sussangkarn, 2003). ${ }^{201}$ 특히, 통화 · 금융위기가 재발 할 경우에 IMF의 과혹한 정책요구조건에 얽매이지 않고 동북아3국으로부터 금융지원을 기대할 수 있다는 점에서 지역적 자금지원협력에 대단히 적극적이다.

18 1987년 마닐라에서 개최된 제 3 차 정상회담에서 특혜무역협정의 대상품목과 관세인하의 확대, 비관세장벽의 재점토, 산 업헙력정책의 강화 등을 주요 내용으로 하는 '마널라선언' 을 채택하고 경제통합을 가속화하기로 합의하여 ASEAN 자유무역 지역 창설에 관한 논의가 본격적으로 전개되었다.

1 ASEM에 대한 논의는 1972년 ASEAN과 EC 사이의 비공식대화로부터 시작하였으며, 1980년에는 ASEAN-EC 공동 위원회를 창설하여 경제협력을 도모해 왔다. ASEM 정산회담은 처음에 1994년 싱가포르 Goh, Chok-dong 총리가 당시 EU 의장국인 프랑스를 방문하고 제의하였으며, 1995년 싱가포르에서 개최된 ASEAN-EU 공동위원회에서 합의하여 1996년 $\mathrm{ASEM}$ 회의가 태국 방콕에서 공식으로 출범했다.

끼 선진국인 싱가포르는 ASEAN제국은 물론 동북아제국과 시장통합을 촉진하고 구조개혁과 경쟁심화로 산업기반을 강 화한다는 이유로 동아시아경제통합에 적극적이다. 말레이시아, 태국, 필리핀, 인도네시아 등 중진국그룹은 한국, 일본으로부터 는 선진기술과 자본을 도입하야 수출공급능력을 확대하고 중국과는 경쟁적인 공존관계를 유지하여 동북아 거대시장에 지출할 수 있는 기회라는 점에서 동아시아경제통합에 적극적이다. 또, 후발국들은 경제개발에 필요한 인프라 확충을 위한 경제협력과 동아시아 · 세계경제와의 통합을 위한 수단으로 동아시아통합에 적극적이다. 
실제로 $\mathrm{CMI}$ 를 출범시킨 ASEAN+3회의를 처음에 소집한 것도 ASEAN이라는 점에 주목할 필요가 있다. 그러나 경제발전단계의 차이로 인하여 동북아제국과 환율공조나 통화통합은 시기상조라는 판단 아 래 동아시아차원에서는 자금지원메커니즘에 중점을 두고 ASEAN 차원에서 통화통합을 추진하고 있다. ${ }^{21}$

한국

대외개방도는 높은 반면, 경제규모가 상대적으로 적고 경쟁력도 약한 한국은 동아시아제국과의 경제 협력이 대단히 중요하다. 또한 한국은 대일 수출경합도가 대단히 높아 달러 - 엔 환율변동에 경제성장이 크 게 영향을 받는다. 1997 년 한국이 외환위기를 경험한 가장 직접적인 요인의 하나도 엔의 대달러환율이 급 속도로 하락하여 원화의 실질실효환율이 큰 폭으로 상승한데 기인하였다. 경제위기 이후 한국은 구조개혁, 경제자유화, 대외개방을 적극적으로 추진하여 대외경제관계가 더욱 중요하게 되었다. 또 한국은 경제의 재 도약을 위한 장기발전비전으로 동북아경제중심을 지향하고 있어 동아시아경제협력이 한국경제의 지속적 인 성장을 위한 견인차로 간주되고 있다. 그 동안 한국은 $\mathrm{ASEAN}+3$ 협력체를 강화하기 위하여 전문가로 구성한 ‘동아시아비전그룹' (East Asia Vision Group), 13개국 정부대표로 구성된 '동아시아연구그룹' (Aest Asia Study Group) 설치를 주도한 바 있다.

한국이 동아시아경제협력의 제도화에 적극적인 배경으로는 첫째, 북한의 개혁과 개방을 유도하고 경 제개발을 지원하기 위해서는 일본, 중국, ASEAN제국 등 역내제국과 연대와 협력을 강화해야 하며, 둘째, 상대적 소국으로서 편향된 요소부존상태와 협소한 시장을 지역협력을 통하여 보완하며, 셋째, 외환위기의 경험에 비추어 역내 환율안정과 금융시스템의 안정이 절대적으로 필요하며, 마지막으로 일본과 중국의 라 이벌관계를 감안하여 한국이 동북아협력에 필요한 외교적 리더십과 지적 리더십을 발휘할 수 있다는 자신 감 등을 들 수 있다.

\section{III. 지역 금융 · 통화협력의 전개와 과제}

\section{1. 동아시아 금융협력의 전개}

경제위기 이후 미국이 주도하는 IMF체제에 대한 불만과 실망은 동아시아지역에서 지역차원의 금융통

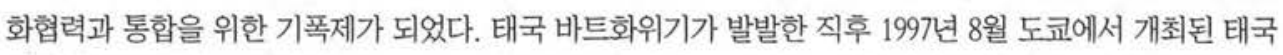
에 대한 금융지원 국제회의 'Friends of Thailand' 에서 IMF 자금 67 억 달러를 외에 총 105 억 달러를 2 국 간 지원으로 제공했다. 2 국간지원의 합의는 동아시아지역의 강한 연대의식의 발로였다. 그 후 인도네시아 통화위기 때에도 동일한 금융지원이 이루어졌다. 외환위기가 절정에 달하던 1997년 12월에는 ASEAN 10 개국과 한 - 일 - 중의 13 개국 수뇌가 역사상 처음으로 ASEAN+3회담을 개최하여 역내금융통화협력을 추 진하기로 합의하였다.

1997년 9월 IMF · 세계은행 연차총회에서 일본은 '아시아통화기금' (AMF) 구상을 제안하였다. AMF 구상은 ASEAN제국과 한국의 적극적인 지지가 있었음에도 불구하고 미국과 IMF의 강력한 반대로 논의 조차 되지 못했다. 이에 동아시아제국의 반발을 무마하고, 또 위기가 동아시아 전 지역은 물론, 역외로까지 확산될 조짐을 보이자 미국과 IMF는 1997년 11월에 '마닐라그룹' (Manila Framework Group, MFG) 결 성을 주도하였다.

${ }^{20} \mathrm{ASEAN}$ 제국은 한, 일, 중과 경제구조가 지나치게 다르기 때문에 동아시아 단일통화가입과 관련한 논의는 아직 없지 만, ASEAN 차원에서 공동통화 도입에 관한 연구를 착수하였다. 하고 있다. 
MFG는 동아시아지역경제의 감시(surveillance), 금융시스템의 강화, IMF의 금융위기 대응능력 제 고, 아시아통화안정을 위한 시스템구축 등 동아시아의 외환위기 극복과 재발방지방안을 목적으로 소집하 였지만, 실재는 IMF의 프로그램을 효과적으로 이행하기 위한 기구였다. ${ }^{20}$

$\mathrm{AMF}$ 구상이 미국의 반대로 좌절되자 일본은 1998 년 외환위기국의 위기극복과 경제회복을 지원할 목 적으로 300 억 달러 규모의 단기 및 중 - 장기자금 공여와 한국, 말레이시아와 쌍무적인 스왑협정체결을 통

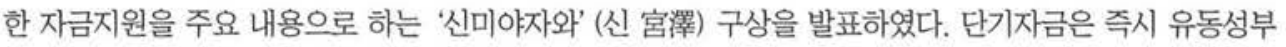
족에 충당하고, 중 - 장기자금은 금융시스템 안정화, 기업부문 구조개혁, 사회안전망 구축에 사용되었다. 이를 계기로 동아시아경제에 대한 신뢰가 회복되어 금융시장이 안정되기 시작했다.

1999년 11월 제3차 ASEAN+3 수뇌회담에서 '동아시아협력을 위한 공동성명서' 를 채택하고 지역차원 에서 자조적인 금융지원메커니즘을 강화하기로 합의하였다. 이로써 논의만 무성했던 동아시아금융협력의 제도화가 정치적 힘을 받게 됐다. 이 공동성명서 정신은 2000 년 5 월 태국 치앙마이에서 개최된 제 2 차 ASEAN+3 재무장관 회의에서 '치앙마이 구상' (Chiang Mai Initiative, CMI)으로 구체화됐다.

금융협력은 일반적으로 유동성지원메커니즘과 역내 환율안정을 위한 통화협력메커니즘으로 구성되며, 현실적으로는 협력의 발전단계에 따라 다양한 형태를 취한다. 금융협력의 초기형태는 특정국이 유동성 부 족에 처해 있을 때 2 국간에 자금을 지원하는 단계에서 역내 공통기금의 설치와 통화통합으로 발전한다. 위 에서 살펴본 바와 같이 동아시아지역에서는 $\mathrm{AMF}$ 구상에서부터 BSA네트워크에 이르기까지 외환위기가 발발할 경우에 자금지원메커니즘을 강화하는데 중점이 돼왔으며 환율안정을 위한 노력은 등한시돼 왔다.

\section{2. 자금지원메커니즘으로서 CMI}

$\mathrm{CMI}$ 는 기존 'ASEAN스왑협정' (ASEAN Swap Arrangement, ASA)의 확대와 ASEAN제국과 한 · 일 · 중 +3제국 사이에 '2국간 스왑협정' (Bilateral Swap Arrangement, BSA)의 주요내용으로 돼있 는데, 자금규모로 보나 그 실효성에 있어 BSA가 CMI 구상의 핵심이라고 할 수 있다. 2003년 3월말 현재 한국, 일본, 중국 등 +3 사이와 +3 과 주요 ASEAN제국 사이에 총 310 억 달러 규모에 달하는 12 개 협정이 체결돼있다. ${ }^{23}$

\section{(1) ASEAN 스왑협정(ASA)}

ASA가 최초로 출범한 해는 1977 년이다. ${ }^{20}$ 그러나 기존 ASA는 1997 년 동아시아위기에 당하여 거의 실 효성이 없었다.

${ }^{2} \mathrm{MFG}$ 는 동아시아외환위기와 관련하여 미국과 IMF가 태국에 대한 2국간 지원에도 극히 소극적이고 AMF 구상에도 노골적으로 반대함으로서 미국과 IMF에 대한 아시아제국의 불만과 비난이 고조되자 이를 무마하기 위하여 주도한 측면이 강 하다. 회원국은 태국에 대한 2 국간 지원을 제공한 8 개 동아시아제국, 호주 이외에 미국, 캐나다, 뉴질랜드의 역외제국과, 필리 핀, 태국이 포함하여 14 개국으로 구성되어 년 2 회 회의를 개최하고 있다.

${ }^{20} \mathrm{BSA}$ 는 +3 의 각국이 10 개 ASEAN제국과 체결하기 때문에 합 30 개, +3 제국 상호간 3 개 등 이론상으로 33 개 협정이 될 것이다. 그러나 2003년 8월말 현재, 한 - 일(70억 딜러), 한 - 중 (20억 달러), 일 - 중 (30억), 일 - 말레이시아(35억 달러), 일 - 태 국, 일 - 필리핀, 일 - 인도네시아(각 30 억), 중 - 태국(20억), 중 - 말레이시아(15억), 한 · 태국, 한 - 말레이시아, 한 - 필리핀(각 10 억) 사이에 12 개 협정이 체결되었으며, 일 - 싱가포르, 중 - 필리핀, 중 - 인도네시아. 한 · 인도네시아 등 4 개 협정이 교섭 중 에 있다. 한 · 일, 일 · 말레이시아의 자금규모는 신미야자와구상의 일환으로 체결된 스왑금액 50 억 달러와 25 억 달러가 포함되 어있다.

${ }^{20}$ ASA는 1977년 8월 인도네시아. 말레이시아, 필리핀, 싱가포르, 태국 등 ASEAN 창설 5 개국이 참여하여 일시적인 유 동성부족이나 국제수지문제에 봉착한 회원국에게 스왑 형태로 단기자금 제공을 목적으로 출범하였다. 출범 시의 자금규모는 각 회원국이 2 천만 달러씩 각출하여 1 억 달러였으며, 이듬해인 1978 년에 각출금과 지원규모를 각 4 천만 달러와 2 억 달러로 2 배 확대하였다. 
그래서 2000년 $\mathrm{CMI}$ 의 일환으로 $\mathrm{ASA}$ 를 확대하기로 합의하여, 회원국을 10 개 전 $\mathrm{ASEAN}$ 회원국으로 늘리고 자금규모도 10 억 달러로 대폭 확대하고, 각국의 출연금도 5 개 창설멤버와 브루나이는 각 1 억 5 천만 달러, 베트남 6 천만 달러, 미얀마 2 천만 달러, 캄보디아 15 백만 달러, 라오스 5 백만 달러로 결정하였다. $\mathrm{ASA}$ 는 각 회원국 국내통화를 달러, 엔, 유로화 등 국제통화와 스왑해주는 일종의 다자간 스왑협정으로 2 국간 스왑협정네트워크인 BSA보다 발전된 형태이지만, 아직도 자금규모가 적어 상징적인 의미에 머물고 있다고 할 수 있다.

자금지원은 당연히 그에 상응하는 감시(surveillance) - 압력(peer pressure) 수단을 구비하여 차입국 의 도덕적 해이를 방지할 수 있어야 한다(Kuroda - Kawai, 2002). ASA도 회원국의 거시경제운영, 금융, 자본, 재정의 건전성과 안정을 확보하기 위한 정책수립과 집행능력을 심의하고 거시경제실적, 자본이동, 환율 등의 동향을 모니터 - 감시하기 위한 ASEAN 감시기구(ASEAN Surveillance Coordinating Unit, $\mathrm{ASCU}$ )를 설치하고 있다. ASCU는 주요 경제 및 금융변수들의 추이를 모니터하고 효과적인 정책수단을 심의하는 2개 메커니즘으로 구성되어 있는데, 각국이 IMF에 제출하는 자료와 동일한 데이터를 바탕으로 아시아개발은행 $(\mathrm{ADB})$ 의 기술적 협력을 받아 아세안제국의 경제 - 금융상황을 분석하고 감시보고서를 작 성한다. 이 보고서를 바탕으로 아세안 재무장관회의에서 각 회원국의 경제전반에 대한 감시기능을 진행한 다. 그러나 ASEAN제국의 '주권존중, 내정불간섭주의' 원칙으로 인하여 도덕적 해이를 방지하기 위한 엄 격한 감시와 압력기능은 아직 충분한 수준에 이르지 못하고 있다.

(2) ASEAN+3 2국간 스왑협정(Bilateral Swap Arrangement, BSA) 네트워크

외환위기 이후 동아시아금융협력에서 가장 획기적인 전개는 $\mathrm{ASEAN}+3$ 의 BSA네트워크이다. BSA 네트워크는 자금규모나 실효성에 있어 ASA와 비교할 수 없을 종도로 유력하여 $\mathrm{CMI}$ 의 핵심을 이루고 있 다. $\mathrm{BSA}$ 의 기본원칙은 전 회원국차원에서 공동으로 결정하고, 개개의 스왑협정은 기본원칙 테두리 내에 서 쌍무적으로 교섭하여 체결한다. 예를 들면, 차입국의 통화와 상대국의 보유 국제통화(달러, 유로화, 엔 등)를 2 국간에 스왑하는데 스왑기간, 적용이자, 경신조건, 발동조건 등 일반원칙은 회원국 전체회의 공동 으로 결정하여 각 협정에 적용한다. 현재, 스왑기간은 90 일이며, 7 회까지 경신할 수 있다. 이자율은 최초 스 왑과 제 1 회 경신기간에는 LIBOR금리에 프리미엄(150점)을 더하고, 그 후에는 매 2 회 경신 때마다 50 점의 프리미엄이 추가되며, 최고 300점을 초과할 수 없다. BSA의 발동에 있어서도 스왑자금규모의 $90 \%$ 는 IMF 프로그램과 연계되어 IMF 정책요구조건이행을 전제로 제공된다. 나머지 $10 \%$ 만이 당사국의 합의에 따라 제공된다. 이렇게 스왑자금 제공을 IMF의 정책이행조건과 연계시킨 이유는 CMI에 효과적인 감시 · 상호 압력(surveillance and peer pressure)장치가 정비돼 있지 않기 때문이다.

$\mathrm{CMI}$ 는 정보교환과 정책감시기능을 강화할 목적으로 경제심의정책협의회(Economic Review and Policy Dialogue, ERPD)를 설치하고, 거시경제정책의 심의, 기업 지배구조의 개선, 역내자본이동의 모니 터링, 국내금융시스템의 강화, 국제금융시스템의 강화, 국제금융체제의 개혁, 상호협력메커니즘의 창설에 관한 임무를 부여하였다. 그 동안 ERPD는 단기자금의 역내이동과 금융시스템의 취약성에 대한 조기경보 시스템 개발에 성공하였지만, ASP와 마찬가지로 아직도 감시 - 상호압력기능에 대해서는 신뢰를 받지 못 하고 있다(Kuroda - Kawai, 2002). 아직 ERPD는 임무수행을 지원할 전담사무국과 감시협의의 절차에 관한 규정이 구비되지 않았다. 
이러한 한계를 극복하기 위하여 2004년 5월로 예정된 ASEAN+3 재무장관 회의에서는 감시기능의 강 화방안, IMF와 $90 \%$ 연계조항의 재검토, 자금규모의 확대 등 CMI BSA의 강화하기 위한 방안이 심도 있 게 논의될 것이다. ${ }^{8)}$ 특히, $\mathrm{ERPD}$ 가 지역 및 각국의 경제현황에 대한 심의 · 평가를 위한 독립적인 전문기 관으로 강화될 것이 확실시 된다.

(3) 마닐라그룹(Manila Framework Group)

앞에서 설명한 바와 같이 외환위기에 대한 미국과 IMF의 소극적인 대응과 역할에 동아시아제국의 불만이 고조되었다. 또 외환위기가 동아시아 전 지역으로 확산되기 시작하였다. 이를 무마하기 위하여 미 국과 IMF는 IMF의 대응역량강화방안을 마련하기 위하여 아시아 - 태평양지역 틀 안에서 MFG 결성을 주도하였다.

MFG는 자금지원과 감시협의의 2가지 요소를 구비하고 있다. '자금협력협정(Cooperative Financing Arrangement, CFA)으로 알려진 자금지원메커니즘은 IMF가 부족한 재원을 다른 국제금융기 관 혹은 역내 - 외 제국으로 하여금 2 국간 지원을 하도록 주선하는 장치이다. 따라서 CFA에 의한 자금협력 은 설령 2 국간 지원일 경우에도, IMF의 프로그램의 일환으로 IMF와 협의 하에 제공되기 때문에 MFG의 감시 기능은 대단히 유력하고 효과적이다.

$\mathrm{MFG}$ 감시는 IMF, $\mathrm{ADB}$, 세계은행, 국제청산은행(BIS) 등 국제금융기관의 협력을 얻어 회원국 재무 부와 중앙은행 책임자들이 철저하고 엄격하게 진행한다. MFG는 또 각국의 국내금융시스템과 감독기능을 강화하는 전문기술협력도 제공한다. 그렿기 때문에 동아시아제국으로부터 반발도 많다. 그들은 자신들에 대한 미국과 IMF의 일방적인 감시만 있을 뿐, 미국이나 IMF가 제공하는 지원도 별로 없을 뿐만 아니라. 그들의 요구도 거의 수용되지 않고 있다고 믿고 있다. 이런 의미에서 $\mathrm{MFG}$ 는 지역차원의 금융협력체 창설 이라는 동아시아제국의 열망을 반영하는 것이라고 할 수 없다.

\section{(4) 당면과제와 전망}

동아시아제국은 지역금융협력을 위한 보다 포괄적이고 항구적인 체제로서 'AMF' 와 같은 성격의 '지 역공동기금 '(regional financing facility)을 창설할 필요가 있다. '지역공동기금 ‘은 역내제국의 일시적 유동성부족을 지원하여 외환위기를 미연에 방지하고 일단 위기에 휩싸였을 때에는 구제 금융을 제공할 뿐 만 아니라, 역내 환율안정을 위한 외환시장개입에 필요한 유동성을 제공하는 역할을 담당해야 한다는 점에 서 ' AMF '의 성격을 가져야 한다. 그 준비단계로서 유일한 대안인 CMI의 BSA네트워크의 강화가 요청된 다. 먼저, 스왑협정이 현재의 2국간(bilateral) 네트워크에서 다자간(multilateral) 협정으로 발전해야 하 며, 스왑발동에 있어 IMF 프로그램과 $90 \%$ 연계를 낮춰 독자적인 지원규모를 확대하고 자금규모도 대폭 늘릴 필요가 있다. ${ }^{20}$ 이에 상응하여 도덕적 해이를 방지하기 위한 회원국간 정보교환과 감시 - 정책압력수 단을 강화하여 엄격한 융자조건(conditionality)을 요구할 수 있는 제도적 장치도 마련해야 할 것이다.

${ }^{25} \mathrm{CMI}$ 의 2국간 자금협력네트워크에서 이론적으로 어떤 나라도 자금을 대여하거나 차입할 수 있는 위치에 있다. 그러나 경제적 현실을 감안할 때. 자금대여국은 경상수지 흑자를 기록하여 막대한 외환을 보유하고 있는 한국, 일본, 중국 등 +3 제국 은 대여국의 위치에 설 가능성이 높다. 따라서 +3 은 자금협력의 발동과 관련하여 상대적으로 엄격한 정책감시능력과 정책이행 조건을 희망하고 효과적인 감시 - 압력기능이 구비되지 않은 현 상황에서는 IMF 프로그램과 밀접한 연계가 불가피하다고 주 장하고 있다. 반면에 자금을 차입할 가능성이 높은 ASEAN제국은 IMF 프로그램으로부터 자유로운 지역차원의 감시기능을 원하고 있다.

201 1997 년 9월 일본이 AMF를 제안했을 때 자금규모 1000 억 달러와 비교하여 현재 체결된 12 개 BSA 네트워크의 총 자금 규모가 310 억 달러는 지나치게 적다. 
여기에서 AMF적인 '지역공동기금' 이란 국제협정에 의하여 가맹국과 각 가맹국의 각출금(quota)을 정하고 전담사무국과 직원을 두어 지역 및 각국의 경제자료 수집분석과 정보교환, 경제정책의 심의, 권고, 감시업무를 담당하며 회원국의 요청이 있을 때 일정한 조건하에서 국제유동성을 공급하는 지역차원의 국 제기관을 말한다. ${ }^{2 n}$ 이러한 기금의 창출로 막대한 저축초과지역인 동아시아제국이 외환위기나 통화투기에 대비하여 개별적으로 외화자산 보유함으로서 지불하는 비용을 지역차원에서 절약할 수 있으며, 자금순환 에 있어 역외의존을 줄일 수 있다. 또한 '지역공동기금' 이 일단 설립되면 뒤에 역내환율안정을 위한 외환 시장개입자금도 지원할 수 있게 된다. 현재 제안되고 있는 지역금융안정프레임워크(IIMA, 2000), 동아시 아기금(Ito-Ogawa-Sasaki, 1999), 역내금융협정(Yoshimoto-Shirai, 2000)은 기본적으로 모두 'AMF' 성격의 공동기금에 다름 아니다.

'역내공동기금' 에 가장 큰 걸림돌은 일찍이 AMF 제안에 대한 미국과 IMF의 반대이유에서 엿볼 수 있듯이, 도덕적 해이를 방지하기 위한 회원국간의 엄격한 감시 - 압력수단을 제도화하는 일이다. 전통적으 로 동아시아제국은 국제관계에 있어 상대국의 국내문제에 개입하지 않은 내정불간섭주의 원칙을 채택하여 왔다. 그러나 강력한 감시 - 압력기능은 이러한 전통과의 마찰은 물론 경제주권의 일부 양여를 의미한다. 이러한 맥락에서 포괄적이고 심도 있는 심의, 공정하고 객관적인 평가, 실효성 있는 정책을 권고할 수 있는 유능한 전문기관의 설치가 대단히 중요하다. 동시에, 각국이 지역적인 감시체제에 기꺼이 참여할 수 있도 록 충분한 인센티브를 제공하는 것도 중요하다. 또한, 각국은 자국이 역내 감시기구의 제반절차를 통과함 으로서 국제사회의 신회와 평판을 얻어 외국인투자를 유치하는데 크게 기여한다는 사실을 인식할 필요가 있다.

역내금융협력은 정부차원의 ‘정책공조' 와 병행하여 민간차원의 ‘시장공조' 도 중요하다. 시장공조는 지역차원의 금융시장 육성과 발전을 위한 인프라 정비가 대단히 중요하다. 즉, 동아시아의 막대한 저축이 역외로 유출하지 않고 역내 투자를 지향할 수 있는 금융시장의 육성과 통합에 공동으로 노력해야 한다. 앞 에서 설명한 바와 같이, 취약한 금융시스템과 금융시장으로 인하여 지역의 막대한 저축이 역외로 유출되기 때문에 부분적으로 자금부족과 외환위기에 노출되는 것이다.

이런 맥락에서 역내기업이나 정부가 역내 금융시장에서 직접 자금을 조달할 수 있도록 자본 · 화폐시 장, 그 중에서도 아시아채권시장(Asia Bond, Markets)을 육성해야 한다. 아시아채권시장의 육성을 위해 서는 첫째, 각국이 자본거래 - 금융거래를 자유화하여 역내시장을 통합하고 자국통화표시의 정부채나 회사 채를 인수 - 유통시킬 수 있는 비거주자 외채시장을 창출해야 한다. 둘째, 채권발행기관에 대한 정보공개, 회계·감독기능의 조정, 채권에 대한 신용을 평가하고 보증할 전담기구의 설립, 결제시스템의 표준화 등 시장인프라의 정비가 필요하다. 셋째, 외환리스크를 최소화하기 위하여 역내환율안정메커니즘을 도입해야 하며, 마지막으로, 장기적으로는 뒤에 설명하는 '아시아통화단위' (Asia Currency Unit, ACU)와 같은 공 통통화단위를 도입하여 공통통화단위표시 채권을 발행하여 환율변동의 리스크를 제거해야 한다.

초보적인 단계이지만, 아시아채권시장의 창설이 이미 착수되었다. 2003연 8월 마닐라에서 개최된 $\mathrm{ASEAN}+3$ 재무장관회의에서 '아시아채권시장 구상' 이 정식으로 채택되었다.

${ }^{2 n}$ 현재의 2 국간 단기자금헙력 네트워크인 CMI와 다른 점은 각 회원국이 미리 일정액이 외화자금을 역내 봉화 - 금융안 정을 위하여 불입하고 회원국 봉화가 투기공격을 반거나 국제수지위기에 처할 경우에 일정한 조건에서 국제유동성을 일시적으 로 대여하는 제도이다. 


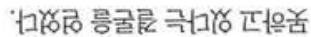

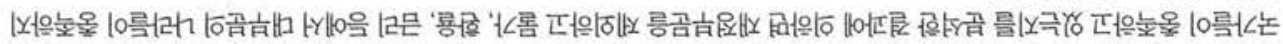

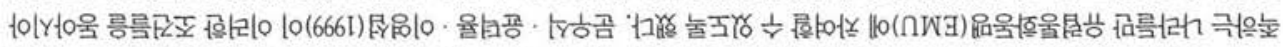

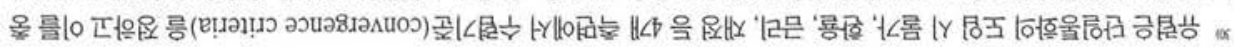

'(666I) Uему

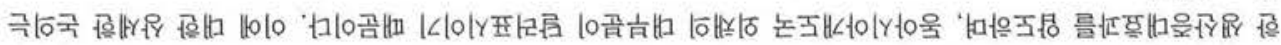

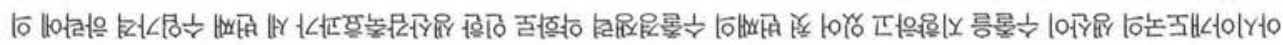

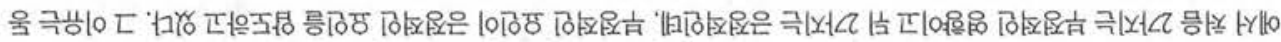

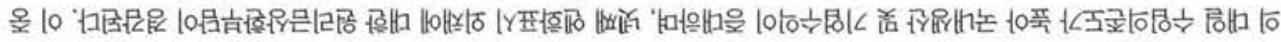

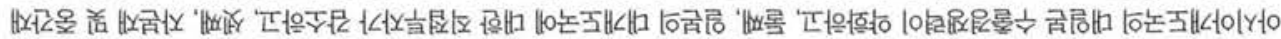

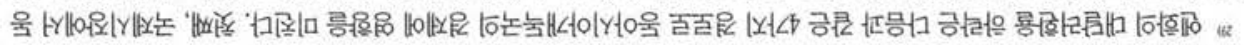

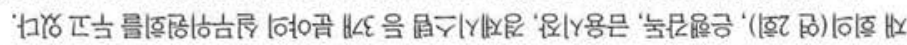

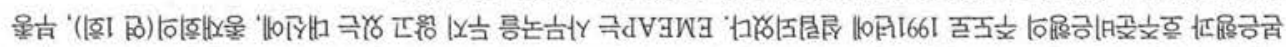

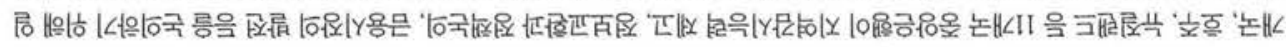

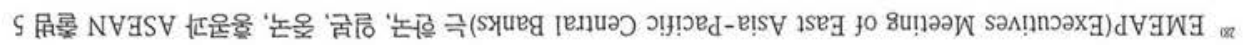

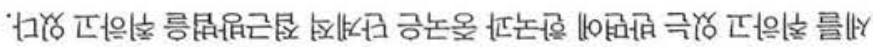

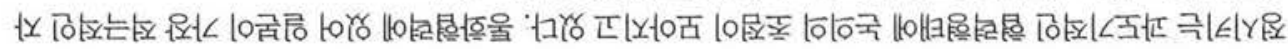

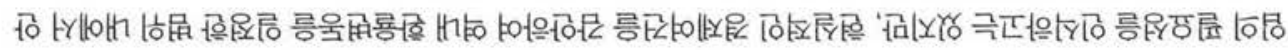

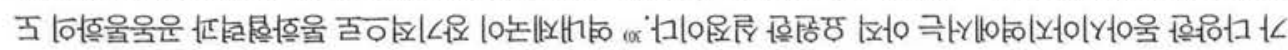

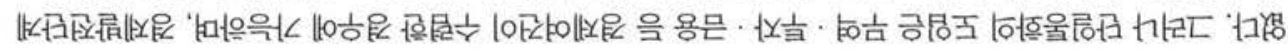

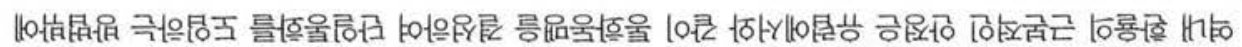

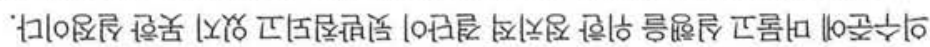

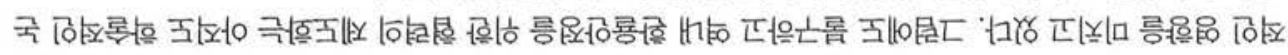

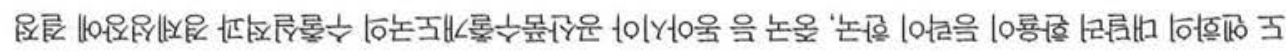

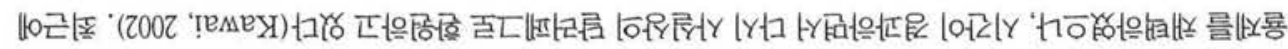

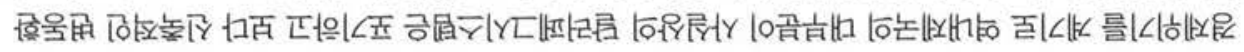

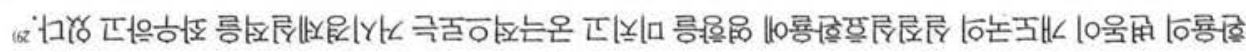

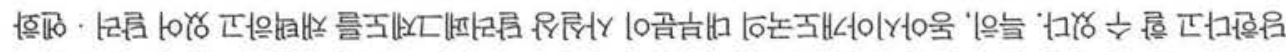

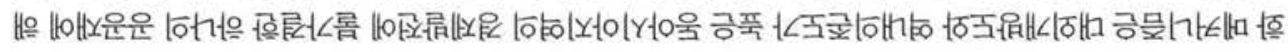

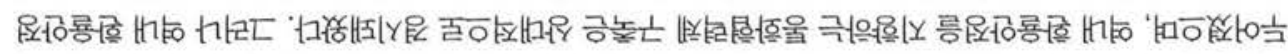

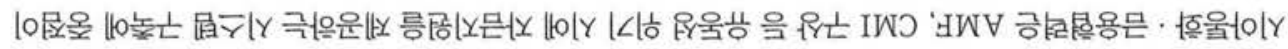

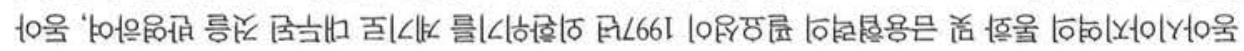

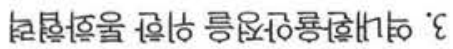

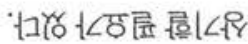

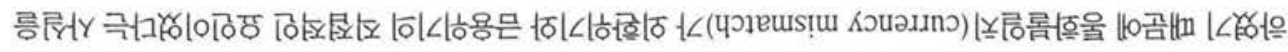

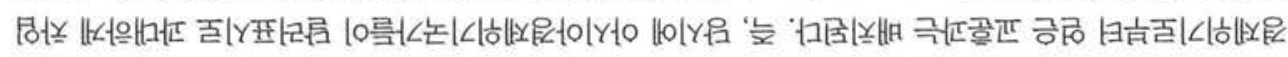

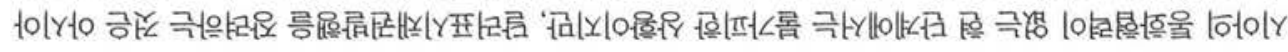

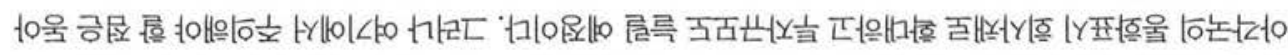

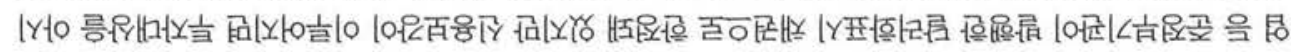

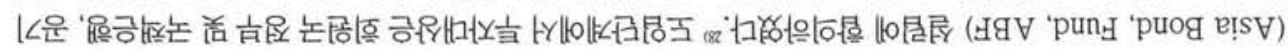

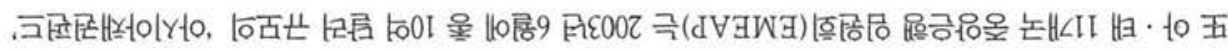


현재 동아시아제국이 채택할 수 있는 방안은 특정 통화 혹은 통화바스켓에 공동으로 페그하는 방안인 데, 달러나 엔과 같은 개별통화의 어느 하나에 페그하는 방안은 달러 - 엔화 환율의 변동으로 실질실효환율 의 변동을 야기하기 때문에 바람직하지 않다. ${ }^{31}$ 달러페그제도가 외환위기의 중요한 요인의 하나였다는 점 은 이미 여러 연구에서 입증되었다(Kwan, 1999; McKinnon, 2001; Ito-Ogawa-Sasaki, 1999; Williamson, 1999). 엔에 페그할 경우에도 마찬가지로 문제가 발생한다. 그렇다면, 수개 통화로 구성되는 통화바스켓에 페그하는 방법밖에 없다.

현재 3 가지 종류의 통화바스켓페그제가 제시되고 있다. 하나는 일본을 제외한 동아시아국가들이 역외 통화인 달러, 엔, 유로화 등 G-3통화에 일정한 가중치를 부여한 통화바스켓에 공동으로 페그하는 'G-3통 화바스켓' 이다(Williamson, 1999; Kawai - Takagi, 2000; Ito, 2001; Kawai, 2002; Ogawa - Ito, 2002; 조종화 - 김우진, 2001). 그 구체적 내용은 일본을 제외한 동아시아개도국 통화를 G-3통화바스켓에 페그한 다. 초기에는 각국이 교역비중을 고려하여 독자적으로 3 개 통화에 가중치를 부여하지만, 점차적으로 가중 치를 공동화하여 G-3 통화간 환율변동 시에 역내환율을 안정시키면서 동시에 G-3통화에 대해서는 변동 할 수 있게 하여 환율의 역내안정성과 역외신축성을 동시에 확보할 수 있다. 가까운 장래에 공식적인 통화 동맹이나 단일 통화의 도입이 어려운 현 단계에서 가장 바람직하고 현실적인 방법으로 평가되고 있다(조종 화 - 김우진, 2001). ${ }^{32}$ 그러나 G-3바스켓시스템은 동아시아 통화 중에서 일본 엔화만이 기준통화를 구성하 게 되어 불공정하다는 비판이 제기되고 있다.

두 번째 제안은 '복수통화바스켓페그제도' 로서 동아시아개도국이 달러와 엔에 가중치를 부여하는 바 스켓에 페그하는 방법이다. ${ }^{31}$ 이 방법은 한국이 1980 년대에 채택하였던 방법인데 교역량 비중에 따라 달러 와 엔에 독자적인 가중치를 부여함으로서 각국의 실효환율 안정에는 도움이 되지만, 역내 환율안정이라는 통화협력의 기본취지에는 부합되지 않는다. 또, G-3통화바스켓보다 엔의 위상이 더욱 높기 때문에 동아시 아개도국이 실제로 채택할 것인지가 의문이다.

마지막으로, 동아시아의 모든 통화를 가중평균한 형태의 '지역통화바스켓시스템' 으로 주로 한국과 중 국 학자들이 제안하고 있다. 지역통화바스켓시스템은 유럽통화시스템(EMS)의 '유럽통화단위' (European Currency Unit, ECU)와 같이 공동화폐로 ‘아시아통화단위' (Asia Currency Unit, ACU)를 창출하여 ACU에 각국통화를 페그하고 역내통화 상호간의 환율변동을 일정범위 이내로 제한함과 동시에 역외통화에 대해서는 자유변동을 허용하는 방법이다. 고 을 제안하고 있다(문우식 · 윤덕룡 - 이영섭, 1999 ; Oh - Harvie, 2001; Wang, 2002). ${ }^{30}$ 일단 ACU가 도입되면 역내의 무역과 자본거래에 사용될 뿐만 아니 라, 준비자산 및 역내 채권발행에도 사용한다. 더 나아가서 ACU 도입은 앞에서 설명한 '지역공동기금' 의 지원을 얻어 각국이 자국통화의 대ACU환율을 안정시키기 위한 개입자금을 지원받을 수도 있을 것이다.

30 역내환율안정을 위해 달러본위제와 같이 동아시아통화의 달러화를 더욱 강화해야 한다는 주장도 있다(Mckinnom, 2001; Mundel, 2001). 이들은 달러본위제는 미국과 경제통합을 심화시키고, 상대적으로 단순하여 환율안정화 비용을 절약할 수 있다는 점을 들고 있다. 그러나 이러한 주장은 동아시아경제에서 미국의 중요성이 감소하고 역내의존도가 증가하는 현실을 경시하고 있다.

${ }_{30}$ 김태준 - 유재원(2000)도 동아시아제국이 지역통화만으로 바스켓을 구성하는 경우와 G-3바스켓을 구성하는 경우의 실질실효환율 분산을 계산 - 비교하여 G-3통화바스켓의 경우 실질실효환율의 분산을 최소화할 수 있어 가장 바람직하다는 결 론을 얻고 있다.

31) Kwan(1999)은 복수통화바스켓의 채택으로 동아시아개도국들이 점차적으로 엔을 국제통화로 사용하고 엔에 대한 환 율안정을 유지하여 장래에 '엔블록' 형성을 의도하고 있다.

x* 지역통화바스켓에는 한국 원, 일본 엔, 중국 인민폐, 싱가포르 달러 등 ASEAN +3 의 13 개국 통화로 구성하며, 각 통화 에 부여하는 가중치는 기본적으로 지역경제에서 차지하는 해당국의 상대적 규모를 기준으로 한다. 이는 유럽에서 유로화를 도 입하기 전인 1979-98년 사이에 EMS 하에서 EMU와 동일하다. 
너음욜

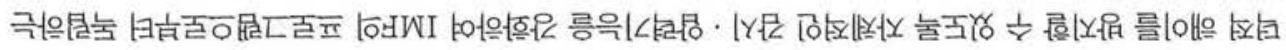

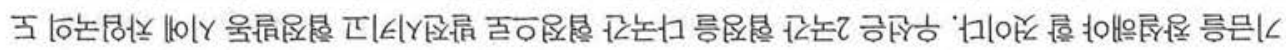

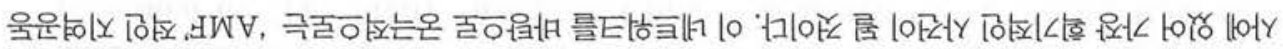
늘용용믄 不

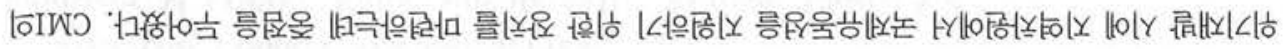

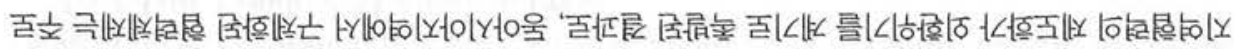

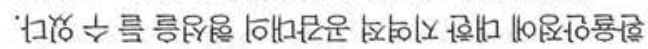

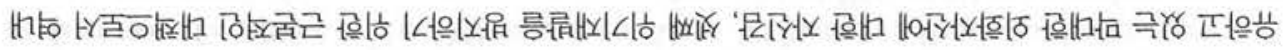

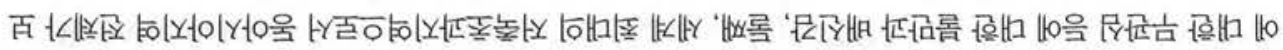

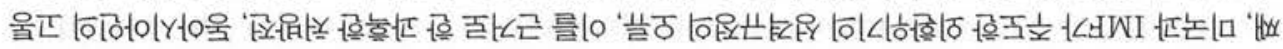

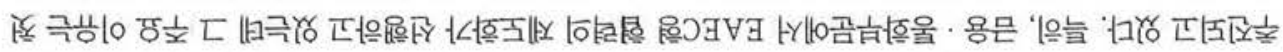

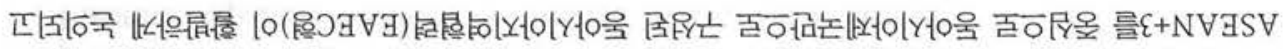

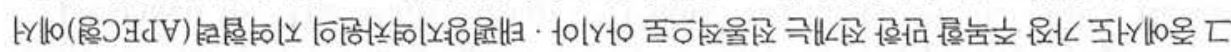

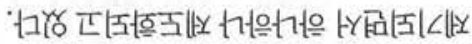

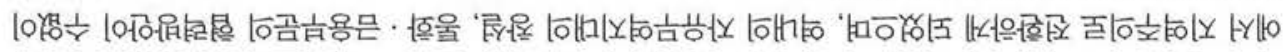

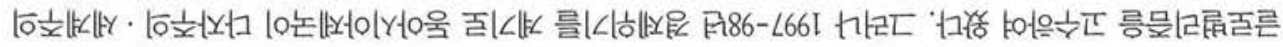

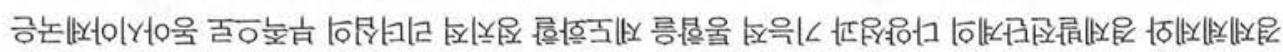

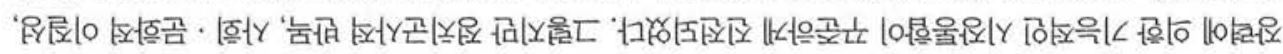

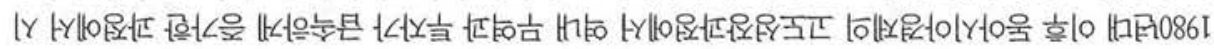

\section{름믕 麻 $\Lambda I$}

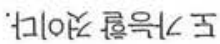

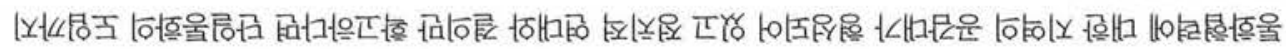

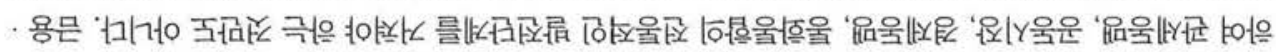

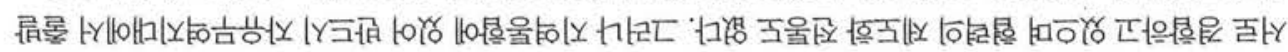

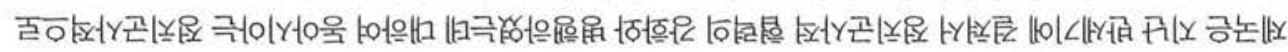

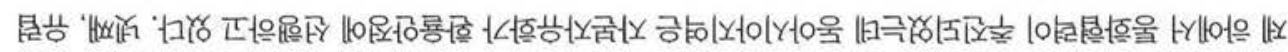

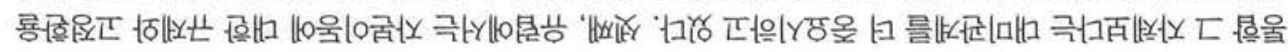

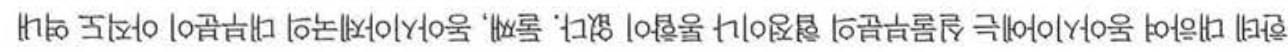

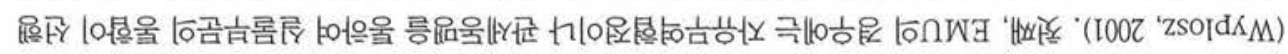

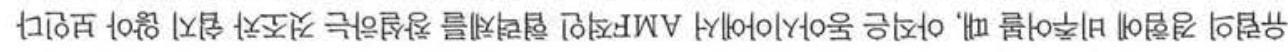

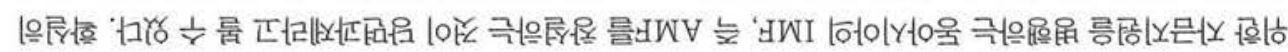

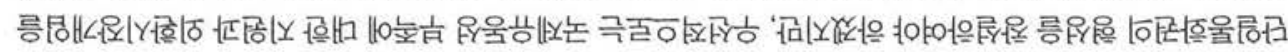

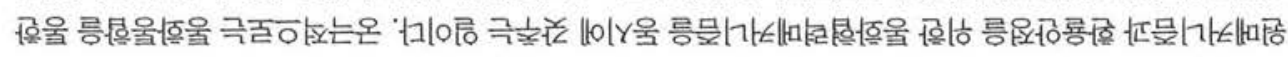

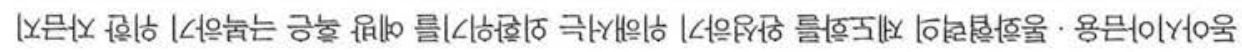

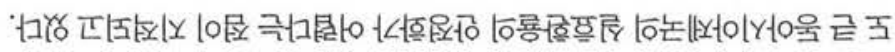

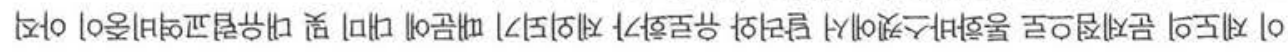

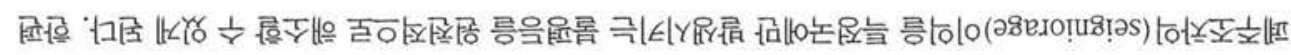

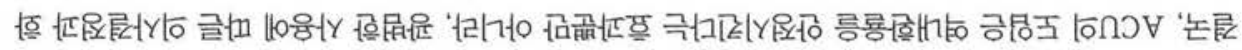


동시에, 정책공조와 병행하여 시장공조를 위한 동아시아의 자본 · 금융시장을 육성할 필요가 있다. 역 내 자본시장의 발달은 동아시아의 막대한 저축의 역외유출을 방지하고 역내투자자금으로 동원하여 외환위 기에 노출을 사전에 방지할 수 있는 가장 효과적인 방안이다.

한편, 자금지원과 함께 지역차원의 금융 - 통화협력의 또 하나의 과제인 역내 환율안정을 위한 통화협 력체의 구축은 학술적인 논의만 무성한 나머지 아직 제도화를 위한 정치적 힘이 뒷받침되지 않고 있다. 그 주된 이유는 환율안정을 위한 협력은 기본적으로 금융정책을 비롯하여 각국의 주요 경제정책의 긴밀한 조 율과 일치, 더 나아가서는 경제주권의 일부가 제한을 받기 때문일 것이다. 그러나 역내 모든 나라가 통화협 력과 역내환율안정의 필요성에 공감하고 있기 때문에 앞으로 협력은 이 분야에 초점이 맞춰질 가능성이 크 다. 근본적인 환율안정은 통화통합으로 단일통화를 도입함으로서 가능하지만 동아시아지역에는 아직 시기 상조이다. 현재 가장 바람직하고 현실적인 방안으로 합의를 얻고 있는 제도는 동아시아개도국이 달러, 엔, 유로화로 구성된 'G-3통화바스켓' 에 공동으로 페그하는 방안이다.

동아시아금융 - 통화협력의 제도화를 완성하기 위해서는 외환위기를 예방 혹은 극복하기 위한 자금지 원메커니즘과 환율안정을 위한 통화협력메커니즘을 동시에 갖추는 일이다. 궁극적으로는 통화통합에 의한 단일통화의 도입을 목표로 하여야 하겠지만, 현재로선 국제유동성 부족에 대한 지원과 외환시장개입을 위 한 자금지원을 병행할 수 있는 동아시아의 IMF, 즉. $\mathrm{AMF}$ 창설이 최대의 과제일 것이다. 동아시아는 아직 도 협력의 제도화경험이 일천하지만, 지역통합에 대한 폭넓은 공감대가 형성되어 뚜렷한 청사진이 제시되 고 그것을 구체화할 수 있는 강력한 정치적 힘이 뒷받침된다면 $\mathrm{AMF}$ 타입의 지역협력기금 창설은 그렇게 어렵지 않을 것이다.

\section{참 고문헌}

김태준 · 유재원(2000), "아시아의 최적통화바스켓과 통화블럭에 관한 연구, 한국은행 『경제분석』, 제6권 제 4 호. 문우식 - 윤덕룡 - 이영섭(1999), 『아시아 통화 - 금융협력: 아시아위기 및 유로화 출범에 대한 대처 방안』. 박영일(1994), "아시아 - 태평양 경제권 형성: 역사적 전개와전망, 명ㅅ상논집젲권 1호, 인하대산업경제연구소 (2000), “아시아경제위기에 대한 '일본책임론' 의 배경과 일본의; 리더십 역할’, 『국제통상연구』제5권 제 1 호, 한국국제통상학회.

조종화 - 김우진(2001), 『동아시아의 통화협력 구상: 역내 환율안정을 중심으로』, 대외경제정책연구원.

Ariff, M. (2003) “The China-ASEAN FTA: A Malaysian Perspective”, paper presented to "The Study Group on China" organized by the Policy Research Institute, Japanese Ministry of Finance, Tokyo, on 19 March.

Bergsten, C.F. (1997) “The Asian Monetary Crisis: Proposed Remedies”, Statement before the Committee on Banking and Financial Service, US House of Representatives, Nov. 13, http://www.iie.crisis.htm(2002).

de Brouwer, G. (2002) "The IMF and East Asia: A Changing Regional Financial Architecture", Pacific Economic Papers, No. 334, AJRC, ANU, Australia.

Deng, Y. (1997) Promoting Asia-Pacific Economic Cooperation: Perspectives from East Asia, London: MaCmillan Press.

Feldstein, M. (1998) "Refocusing the IMF", Foreign Affairs, Vol. 77.

Feridhanusetyawan, T. (2003) “ASEAN-China FTA: A View from Jakarta”, paper presented to "The Study Group on China" organized by the Policy Research Institute, Japanese Ministry of Finance, Tokyo, on 19 March.

Grenville, S.A. (1998) The Asian Economic Crisis, Reserve Bank of Australia Bulletin, April. 
IMF (1999) “The IMF' s Response to the Asia Crisis” IMF website.

Institute for International Monetary Affairs(IIMA) (2000) Workshop on the

Framework for Regional Monetary Stabilization in East Asia, Tokyo.

Ito, T. (2001) "The Role of the Yen in East Asia”, paper presented to the conference on "Monetary Outlook on Est Asia in an Integratory World Economy", held in Chulalongkorn University, Bangkok on 5-6 Sept.

(1999) E. Ogawa, and Y. Sasaki, "Establishment of the East Asia Fund", Institute for Monetary Affairs(ed.), Stabilization of Currencies and Financial Systems in East Asia and International Financial Cooperation, Tokyo.

Kawai, M. (2002) "Exchange Rate Arrangements in East Asia: Lessons from the 1997-98 Currency Crisis”, Monetary and Economic Studies(Special Edition), No. 20, Institute for Monetary and Economic Studies, Bank of Japan, Tokyo.

(2001) "Recommending a Currency Basket System for Emerging East Asia", paper presented to the conference on 'Regional financial Arrangements in East Asia' held in the ANU, Australia on 12-13 November.

and S. (2000) Akiyama, "Implications of the Currency Crisis for Exchange

Rate Arrangements in Emerging East Asia”, mimeo, World Bank. and S. (2000) Takagi, "Proposed Strategy for a Regional Exchange Rate Arrangement in Post-Crisis East Asia”, Policy Research Working Paper, No. 2502, World Bank.

Kwan, C.H. (1999) "Towards a Yen Bloc in Asia”, NRI Quarterly, Summer. (1994) Economic Independence in the Asia-Pacific Region: Towards a Yen Bloc, New York: Routledge.

Kurod, H. and M. Kawai (2002) "Strengthening Regional Financial Cooperation in East Asia” Pacific Economic Paper, no. 332, AJRC, ANU, Australia.

Lee, H.H. and D.Y. Yang (2001) "Reforming the International Financial Architecture", in T.J. Kim and D.Y. Yang(eds), New International Financial Architecture and Korean Perspectives, Korea Institute for International Economic Policy,Seoul.

Martin, W. (1997) "Same Old IMF Medicine", Financial Times, 9 December.

McKinnon, R.I. (2001) “After the Crisis, the East Asian Dollar Standard Resurrected", paper presented to the conference on 'Monetary Outlook on East Asia in an Integratory World Economy', held in Chulalongkorn University, Bangkok on 5-6 Sept.

Mundell, R. (2001) “Currency Area Formation and the Asian Region”, paper presented to the conference on "Monetary Outlook on East Asia in an Integratory World Economy, held in Chulalongkorn University, Bangkok on 5-6 Sept.

Ogawa, E. (2000) "East Asian countries Return to the Dollar Peg Again?", mimeo, Hitotshbashi University, Tokyo. and T. Ito (2002) "On the Desirability of a Regional Basket Currency Arrangement", Journal of the Japanese and International Economies, Vol. 16.

Oh, J. and C. Harvie (2001) "Exchange Rate Coordination in East Asia", paper resented on 'Conference on New Regionalism in East Asia' organized Industrial Research Institute, Sungkyunkwan Univ. Korea, The Institute for Industrial Research, Kangwon National Univ. Korea, Faculty of Economics, Keio Univ. Japan, and International Business Research Institute, Univ. of Wollongong, Australia, held at Hotel Shilla on 11 May. 
Park, Young-il (2003) "Toward Regional Monetary Cooperation in East Asia", paper presented to the 4th Inha-Le Havre International Conference on 'Regional Cooperation and Economic Integration: European and East Asian Experiences' held in Inha University, Incheon, Korea on the 8-9 October.

Roubini, N. (1998) “What Caused Asia's Economic and Currency Crises and its Global Contagion?", the New International Business Web Site at the Stern School of Business, N.Y. University, www.stern.nyu.edu.

Sachs, J. (1997) "Power unto Itself", Financial Times, 11 December.

Sussangkarn, C. (2003) "Thailand and the China-ASEAN FTA: A Personal View", paper presented to "The Study Group on China" organized by the Policy Research Institute, Japanese Ministry of Finance, Tokyo, on 19 March.

Wade, R. and F. Veneroso (2002) "The Resources Lies with", the Economist, November, 1998.Wang, T., "Policy Recommendations on How to Strengthen Financial Cooperation in Asia", in IIMA(ed.), Report on the Study Group on Strengthening Financial Cooperation and Surveillance, Tokyo.

Williamson, J. (1999) "The Case for a Common Basket Peg for East Asian Currencies", in S. Collignon, J. Pisani-Ferry and Y.C. Park (eds.) Exchange Rate Policies in Emerging Asian Countries, London: Routledge.

World Bank (1993) The East Asian Miracle: Economic Growth and Public Policy, Oxford University Press, New York.

Wyplosz, C. (2001) “A Monetary Union in Asia? Some European Lessons”, KIEP, Journal of International Economic Studies, Vol. 5, No. 2.

Yamamoto, T., P. (2001) Thiparat, and A. Ashan, America's Role in Asia: Asian Views, The Asian Foundation, San Francisco.

Yoshitomi, M. and Ohno (1999) "Capital Account Crisis and Credit Contraction: A New Nature of Crises Requires New Policy Papers", ADB Institute Working Paper.

Yoshitomi, M. and S. Shirai (2000) "Policy Recommendations for Preventing Another Capital Account Crisis,” ADB Institute Technical Background Paper.

Young,O. (1990) "Political Leadership and Regime Formation: On the Development of Institutions in International Society", International Organization, Vol. 45 no. 3.

Zhang, Y. (2003) "China-ASEAN FTA under the Framework of East Asia Integration", paper presented to "The Study Group on China" organized by the Policy Research Institute, Japanese Ministry of Finance, Tokyo, on 19 March. 